\title{
The case for capital account management in emerging market economies: The experiences of the BRICs
}

\author{
Joerg Bibow*
}

\begin{abstract}
Currency market intervention cum reserve accumulation has emerged as the favored "self-insurance "strategy in recipient countries of excessive private capital inflows. This paper argues that capital account management represents a less costly alternative line of defense deserving renewed consideration; especially in the absence of fundamental reform of the global monetary and financial order. Mainstream arguments in favor of financial globalization are found unconvincing. It is argued that any indirect benefits allegedly obtainable through hot money inflows are equally obtainable without actually tolerating such inflows. The paper investigates the experiences of Brazil, Russia, India and China (the BRICs) in the global crisis and subsequent recovery, focusing on their respective policies regarding capital flows.

JEL classifications: $\mathrm{F}_{02}, \mathrm{~F}_{32}, \mathrm{~F}_{33}, \mathrm{~F}_{39}, \mathrm{G}_{2} 8, \mathrm{O}_{23}$

Keywords: capital flows, self-insurance, capital controls, financial regulation
\end{abstract}

* Skidmore College and Levy Economics Institute, New York, USA. This paper was presented at the Research Network Macroeconomics and Macroeconomic Policies conference in Berlin in October 2010 and at the Eastern Economic Association meeting in New York City in February 20II. I am grateful for comments from conference participants, especially Esteban Pérez Caldentey, and two anonymous referees.

\section{Correspondence Address:}

Jörg Bibow, Economics Department, Harder Hall 204C, Skidmore College, 8I5 North Broadway, Saratoga Springs, NY I2866, e-mail: jbibow@skidmore.edu.

Received o8 March 20II, accepted I4 September 20II

(C) INTERVENTION 9 (I), 20I2, 57-90 


\section{Introduction}

In 2008 , the crisis at the core of global finance provoked a »sudden stop/reversal« in private capital flows towards emerging market economies (EMEs). This followed a bonanza episode that saw at its final stage an unprecedented "decoupling« surge in 2007. While the global financial crisis (GFC) hit EMEs quite indiscriminately, differences were observed in relative vulnerability to the global shock. Similarly, while a "two-speed recovery« describes an important divide between EMEs and advanced economies in general, experiences among EMEs again show considerable diversity. Broadly speaking, the most important factors determining countries' recovery fortunes were their pre-crisis external positions and their policy space, defining their respective scope for implementing stimulus measures. Countries that were dependent on external help (IMF loans etc.) and export recovery generally fared worse. As financial globalization has severely reduced EMEs policy space and increased their vulnerability. The attractiveness of defensive macroeconomic policies designed to counter these adverse conditions rose accordingly.

This paper investigates whether capital account management (CAM) may contribute to shoring up EMEs' macroeconomic and financial stability and enlarging their policy spacewhile avoiding the costs associated with »self-insurance" strategies. Focusing on the BRICs, insights concerning the design of effective capital account management regimes are sought.

Section 2 critiques the idea of financial globalization as a development strategy supposed to foster catching up. While any supposed benefits may be illusory rather than real, financial globalization has important downsides: the periphery gets coupled to the monetary policy stance set at the center while risking financial instability through exposure to global financial conditions. Especially in the absence of fundamental reform of the international order, instead of taking recourse to self-insurance as the apparent default option EMEs should explore CAM, the underlying rationale and principles of which are discussed in section 3. Section 4 investigates the BRICs experiences in the GFC. Section 5 concludes.

\section{Financial globalization and US monetary policy}

In the 1980s, liberalizing financial markets including cross-border capital flows and asset holdings became a policy mantra around the world. Promoted by international organizations such as the IMF, OECD, and EU (Abdelal 2007), the "Washington Consensus« strongly influenced policies in many developing countries. The main argument put forward for liberalizing capital flows stresses relative capital scarcity in poor countries, in the sense of a lack of domestic saving. By opening up their capital accounts developing economies gain access to the large saving pool of advanced economies, allowing welfare-enhancing augmentations of their own insufficient home savings; supposedly leading to higher investment.

Other promises feature enhanced microeconomic efficiency and macroeconomic stability arising as so-called »indirect or collateral benefits« (Prasad/Rayan 2008). Microeconomic efficiency gains occur as developing economies' incomplete and underdeveloped financial 
markets are exposed to foreign competition, with capital inflows driven by foreign expertise promoting efficiency in resource allocation. Competitive pressures and foreign expertise also deliver macroeconomic stability gains, as the presumed wisdom of markets disciplines policymakers and encourages better institutions and practices. As individuals and firms are offered an enlarged set of opportunities for risk diversification, economies are supposed to experience greater stability in consumption and investment. As a consequence of closing the supposed »saving gap « and obtaining guidance from "wise finance«, financially integrating developing economies experience rising investment rates and accelerated catching-up. „Crossborder flows spur growth and development, benefiting everyone« (BIS 20II: 33).

At varying degrees financial globalization has become a reality in many developing countries; welcomed by market players keen to explore the opportunities on offer in newly opened »emerging markets". Actual outcomes have been sobering.

Most irritating is the increased incidence of financial crises in EMEs in the era of unfettered global finance - until the early 200os. Instead of gaining in efficiency and stability the experience of EMEs is scattered with gravely disruptive financial crises, often leaving permanent structural and socio-economic scars in their trail (Ocampo/Stiglitz 2008). For what actually happens when a country opens up to global finance and becomes the target of capital flows is currency appreciation and a corresponding loss in competitiveness (Combes et al. 20II). It is in this way that a current account deficit arises that makes the target country of private capital flows a recipient of foreign saving (in the ex post national income accounting sense). In a self-fulfilling and ultimately destabilizing fashion rising asset prices and currency appreciation arouse herding among foreign investors financing the boom. Lured by higher prospective rates of return than seem available in home markets, risks may appear low for a while, especially since liberalized financial markets promise the option of getting out at any time. Typically, it is consumption spending (by the privileged few) rather than investment that gets stimulated through currency appreciation and rising asset prices - at least temporarily. Fragile financial structures and vulnerabilities build up through rising indebtedness as the bonanza runs its course and bubbles inflate - until they burst.

Essentially, financial globalization means that the liberalizing developing country is losing both monetary policy autonomy and control over its financial system. Monetary policy space is lost as the EME can no longer pursue a monetary policy course that deviates from the global stance without risking provoking capital flows and exchange rate movements that might counteract its own policy intentions. At the same time, global financial conditions become freely transmittable to the domestic financial system through cross-border flows and dealings.

The point is that there may be very good reasons for preventing the free transmission and arbitraging of financial conditions set elsewhere in the global economy, precisely because these conditions may not be equally appropriate for every country. Similarly, there may be very good reasons for countries not to be subjected to a monetary policy stance determined externally. Far from being an optimum currency area, subjecting the world economy to uniform monetary and financial conditions makes little sense. 
The promise of floating exchange rates as safeguarding countries' policy space heroically presumes that well-behaved market forces would guarantee continuous international equilibrium (Friedman 1953, Johnson 1969). The evidence is otherwise: exchange rate movements neither compensate for inflation differentials (except for in the very long run; Edison 1987, Rogoff 1996). Nor do floating currencies enjoy the degree of freedom under financial globalization implied by the "unholy trinity " (Tobin 1974, Taylor 2004). Over any policy-relevant horizon carry-trade asset market play attracted by interest-rate differentials undermines policy autonomy, easily resulting in destabilizing currency market behavior. It is true that, ultimately, exchange rates are mainly driven by monetary policies rather than market forces. Only that monetary policies were not all made equal.

With the US dollar standing at the top of the international currency pecking order, US monetary policy effectively sets the benchmark for global monetary conditions. Strongly influencing exchange rates and global financial conditions, financial globalization actually maximizes the lead country's financial fire power; mirrored by the loss in monetary policy space and control over domestic financial conditions in the liberalizing periphery. ${ }^{\mathrm{I}} \mathrm{O}$ course exchange rate movements and financial conditions as driven by the lead country's monetary policy may be in conflict with local requirements in the periphery. In other words, a policydomain problem afflicts the financially globalized economy: the peculiar economic conditions ruling in the lead country largely determine global monetary conditions.

For apart from possible contagion effects arising during crises, under non-crisis conditions, the typical EME's influence on global monetary and financial conditions is negligible individually. An impact on global conditions may still arise indirectly in the aggregate though, especially through the following international trade feedback loop. A keenness to export that is widespread in the periphery will create a tendency for labor market weakness at the core, prompting monetary easing in an attempt to stimulate domestic demand at the core. It is in this indirect way that the periphery may exert some influence on global monetary and financial conditions, albeit without any guarantee that the outcome might really suit local requirements at any time. US monetary policy is set with a view to best meet US domestic requirements. But under financial globalization US monetary policy also sets the standard for global monetary policy.

While these reflections on the global monetary and financial order already indicate that financial globalization may be a thoroughly bad idea, it is useful to investigate some broad trends and episodes since the rise in global finance in the I990s.

Following the drawn-out struggle to overcome the I980s developing country debt crisis concentrated in Latin America, in the I990s, private capital flows pushed voraciously toward East Asian destinations - heralding the region's coming predicament. The Asian crises of the late I990s then ended the first capital flow bonanza reaching EMEs since the start of the liberalization frenzy. Large deficits had opened up in the course of the I990s as private capital inflows led to real currency appreciation, credit and asset price booms, and domestic demand expansions

I There may be some secondary currencies with certain reserve currency qualities, enjoying some limited degree of financial independence and influence on global monetary and financial conditions. 
Figure I: EME crises of late Iggos mark a watershed

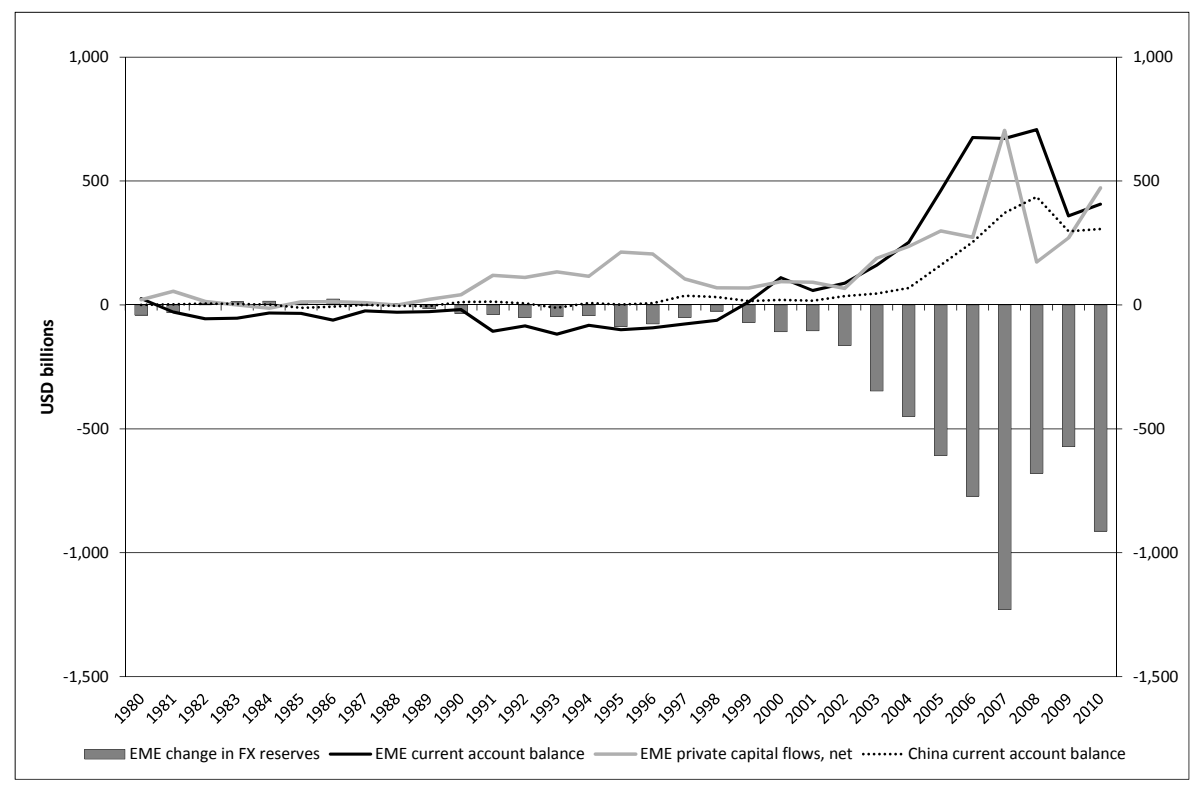

Notes: EME series include the WEO group »Emerging and developing economies" plus Korea.

For the »change in FX reserves" series a minus sign indicates an increase. For the "private capital flows« series a plus sign indicates net inflows.

\section{Source: IMF WEO database (April 2011)}

in recipient countries. The developing world's aggregate current account balance shifted into surplus in the aftermath of the Asian crises (Figure I). Apart from crushing economies, the EME crises also restored competitiveness, allowing export-led recoveries.

Having experienced the hazards of unfettered global finance many EMEs have shown a preference for defensive macroeconomic policies ever since. Defensive macroeconomic policies are centered on avoiding the vulnerabilities that arise from (large) current account deficits and foreign indebtedness, which requires resisting exchange rate pressures driven by private capital inflows and typically involves sterilized currency market interventions. Since maintaining a competitive exchange rate is oiling the engine of export-led growth, Krugman (20I0) described this strategy as "neo-mercantilism». In the event, the buildup of foreign exchange reserves that arises as a by-product may actually be sourced from both private capital inflows as well as current account surpluses, feeding the "self-insurance" reserve buffer (Bibow 2008).

A common policy focus on competitiveness is central to defensive macro policies, and it conveniently suits neoliberal interests of keeping a lid on wages. But widespread keenness to export in the periphery has important systemic implications. For it magnifies deflationary 
tendencies at the core and requires the reserve currency issuer to "overspend " (i.e. benignly neglect its current account deficit). This is the feedback loop through international trade mentioned above. Labor market weakness calls the Federal Reserve into action, enticing the needed (over-)spending.

In turn, easy monetary conditions set at the center of the global financial system also provide the key push factor for capital flows. Similar to the first wave of the I990s, the second capital flow bonanza headed towards EMEs too arose in an environment of easy money policies by the US Federal Reserve - prompted by cyclical weakness in the US economy. Feeding the periphery's bloated self-insurance buffer, official recycling of private capital flows allows the extraction of a "premium " on the part of the reserve currency issuer (see below). ${ }^{2}$

Recipient countries face two principle policy choices in resisting currency appreciation arising from Federal Reserve easing. One is to simply follow suit - implying a complete loss of policy autonomy. The other is to try to recapture some policy space by currency market intervention in support of the dollar. As the second wave took off in earnest in 2002, the periphery's response was a mixture of these two policy options, resulting in soaring FX reserve holdings - much in contrast to the I990s. Dubbed the "global capital flows paradox" (Summers 2006), arguably, the self-insurance boom of the 2000 also revealed a preference among EMEs to avoid multilateral insurance (or, rather, conditionality). 2007 became a record year for capital flows towards supposedly »decoupling « EMEs, with surging equity and commodity price indices and dollar weakness seen across the board.

The situation began to change in early 2008 , at first gradually, then abruptly in the context of the Lehman bankruptcy. The Federal Reserve's role as benchmark setter of global monetary conditions was on display when the US central bank acted as international lender of last resort. As global interbank lending froze up, the Federal Reserve - as the ultimate source of dollar liquidity - substituted for global dollar money markets, providing dollar liquidity through a network of bilateral swap arrangements set up for I4 central banks around the world. The "global dollar gap « quickly eased again and dollar emergency liquidity provision by the Federal Reserve was largely reversed by mid 2009 (Figure 2). By that time private capital flows had once again started to reverse direction: enticed by a fresh round of ultra-easy Federal Reserve policy (Figure 3), private capital outflows were feeding a new "global dollar glut". Erupting at the very core of the system, the GFC had severely impacted advanced economies and EMEs alike. While the globally coordinated reflationary policy response halted the GFC, only EMEs were bouncing back from the abyss vividly.

2 The notion "exorbitant privilege« as applied to the reserve currency issuer in the pre-financial globalization era referred to the goods and services (trade deficit) or direct investments (private FDI outflows) enjoyed or acquired by the reserve currency issuer that had low-yielding official reserve holdings in the periphery as their counterpart. Financial globalization has expanded the opportunities for rent extraction on the basis of much larger gross capital flows meeting increased demands for safety in the periphery (Bibow 20IOa). Typically self-insurance reserve buffers imply the payment of a "premium" by self-insuring recipient countries. For instance, if the reserve currency is used as carry-trade funding currency the intervening authorities in the recipient country effectively act as counterparty in these carry trades, paying a "carry-trade premium» to the carry traders. 
Figure 2: Fed as international lender of last resort

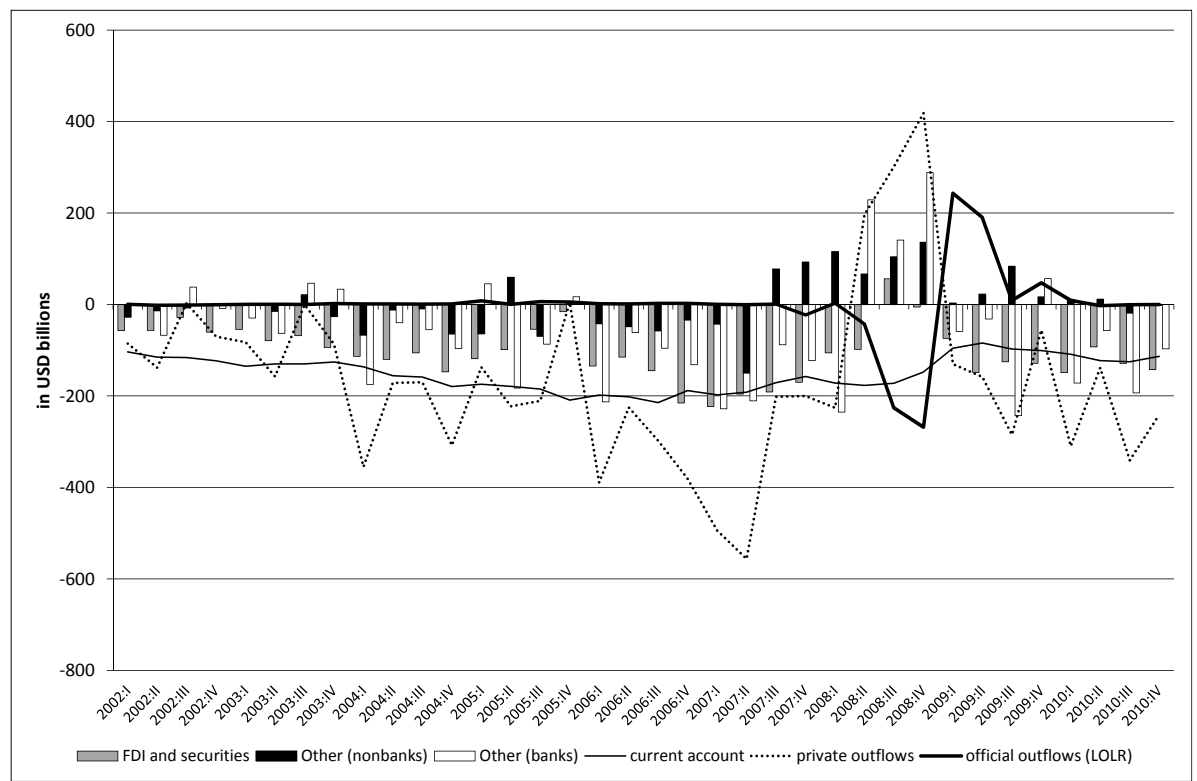

Note: All series for US (gross) capital outflows and current account are quarterly data.

Source: BEA (June 2011)

The multi-speed recovery from the GFC underlines that the world is not an optimum currency area. $\mathrm{G}_{3}$ countries continue to require extra doses of ultra-easy monetary policies. In particular, in view of the poor state of the US labor market the Federal Reserve is bound to maintain its ultra-easy policy stance for an extended period of time. The domestic impact of the monetary stimulus is hampered by the fact that parts of the US financial and household sectors remain in deleveraging mode. Arguably, under these conditions, expansionary US monetary policy develops its greatest impact beyond US borders. The argument that EMEs should allow market forces to determine their exchange rates ignores the fact that foreign monetary policy decisions rather than free markets are the key drivers of "market-determined " exchange rates. Already before the Federal Reserve's latest monetary stimulus plans (»QE2«) were aired in August 20IO, EME's predicament had become focused on containment of the renewed liquidity flood reaching their shores. Confronted with a new wave of private capital inflows, also featuring a composition change away from FDI towards »hot money" flows ${ }^{3}$, recipient countries are challenged in designing policies that might prevent renewed destabilization of their economies.

3 Carry-trade volumes are especially hard to estimate. We use a broad definition of hot money including all short-term portfolio flows as well as cross-border banking and other credit flows unrelated to trade, in particular. 
Figure 3: US easy money pushes capital flow bonanzas

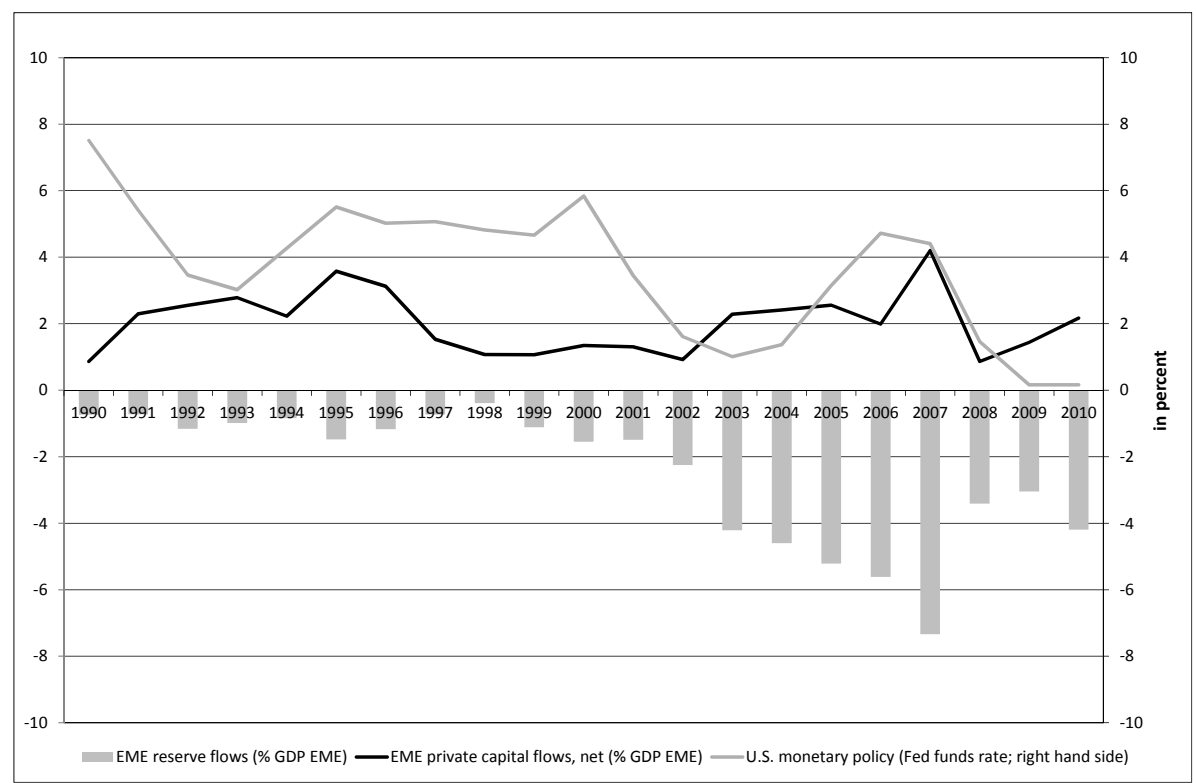

Notes: EME series include the WEO group "Emerging and developing economies" plus Korea, shown in \% of GDP. For the "change in FX reserves" series a minus sign indicates an increase. For the "private capital flows" series a plus sign indicates net inflows.

Source: IMF WEO database (April 2011)

\section{Capital account management: rationale and principles}

With no fundamental reform of the global order in sight, recourse to self-insurance strategies remains EMEs' default option. The crisis experience may further encourage this response. Some rather disconcerting facts exist though. First, self-insuring countries were not spared infection and turmoil. In the event, self-insurance merely provided some margin of safety enabling countries to avoid IMF rescue and securing some - varying - policy space for implementing countercyclical policies on their own (Bibow 2orob). Second, self-insurance comes at a significant cost. Essentially, self-insurance has EMEs swap ownership of higheryielding assets for lower-yielding ones (Bibow 2008-9). For recipient EMEs the ballooning volume of currency market interventions (and sterilization measures) required for containing upward currency pressures means boosting the transfer of resources to rich countries (Bibow 2OIOa). Finally, there is the important systemic issue that EMEs' pursuit of self-insurance requires a counterparty willing to underwrite insurance on demand. 
Rather than waiting for proper global reform while continuing to passively adapt to policies set at the center with only limited policy space reclaimed through costly selfinsurance, EMEs may aim at keeping out what they do not need, namely through a CAM regime. IMF regulations actually allow for this possibility. OECD and EU regulations as well as bilateral agreements may present more of an obstacle. Arguably, flawed doctrines and vested interests are the most important hurdles to overcome.

The aims of a CAM regime are threefold. The first objective is to safeguard financial stability by reducing exposure to unfettered global finance. Experience shows that global finance is far from benevolent and well-behaved. EMEs have every reason to contain risks arising from capital inflows that do not serve their development. The second objective is to safeguard macroeconomic stability and enlarge policy space. Given that the world is not an optimal currency area, delinking from global monetary and financial conditions as set at the center is the essence of the exercise. The third objective is to avoid the costs that arise by relying on self-insurance rather than CAM in the pursuit of the first two objectives.

Note that the proposal here is for a permanent rather than a temporary regime and that the focus is on capital inflows rather than outflows. ${ }^{4}$ Instead of blocking flighty outflows when crisis strikes, it makes far more sense to prevent financial vulnerabilities from arising in the first place, namely by blocking types of inflows that can easily turn flighty (Goodhart/ Delargy 1998). So the regime is to be selective as well, with CAM concerning both the composition of inflows as well as their aggregate volume (Bibow 2008-9).

The »saving gap« idea is the key doctrinal flaw behind the financial globalization mantra. The mainstream (neoclassical) vision of capital accumulation has saving causing and somehow financing investment. This vision is utterly confused and thoroughly misleading. In monetary production economies capital is not saved and grown, but produced; with production requiring advance finance that allows paying the factors of production in monetary units before the output can be sold. Capital formation thus requires liquidity, as created and allocated by the financial system, rather than (ex ante) saving.

"We have all been brought up [...] in deep confusion of mind between the demand and supply of money and the demand and supply of savings; and until we rid ourselves of it, we cannot think correctly", as Keynes (I939, JMK I4: 285) astutely observed on this crucial matter (see also Bibow 2009, Borio/Disyatat 20II, UNCTAD 2006).

The enlightened Keynesian vision therefore stresses that, while growth and development require investment, investment is driven by aggregate demand which, in turn, is susceptible to macroeconomic policies. In the context of developing countries in a globalized world, it is capital goods rather than "capital« that may need to be imported. Any need for external finance of domestic investment only arises if imports cannot be paid for by exports.

Sufficient policy space for deliberate macroeconomic management in line with domestic requirements is thus vital. It is the lack of policy space entailed by financial globalization which tends to bias macroeconomic policies of EMEs towards (net) exports rather than domestic

4 A recent mood change in the debate includes the IMF (see IMF 20IO and Ostry et al. 20IO, 20II), showing greater tolerance of capital controls, albeit only as a last resort and as temporary measures. 
demand as their driver of growth. Ideally both fiscal and monetary policies should be tuned so as to be conducive to steady domestic demand growth, complemented by a competitive exchange rate that allows for the "payment" of imports by means of exports. In practice financial globalization relegates monetary policy to the passive adaptation to conditions set at the center. While self-insurance may recapture some limited space for monetary policy, fiscal policy too tends to get subordinated to external conditions as (net) exports take on a superficially prominent role in aggregate demand.

Importantly, criticizing export-led growth strategies for their neo-mercantilist character is beside the point when policies are chosen defensively as EMEs try to protect themselves against the hazardous environment that the international monetary (non-)order joined by unfettered global finance is posing to their development. That said, the relative success of neo-mercantilism in EMEs certainly undermines the "saving gap « idea, which is contradicted by evidence showing that "developing countries that have relied less on foreign finance have grown faster in the long run " (Prasad/Rajan/Subramanian 2007). It does not take tapping any foreign saving pool to grow and catch up. But it is indeed curious that development should come along with an uphill resource transfer, which is precisely what the current neoliberal global order is extracting from developing countries (cf. UN 2OII).

The "wise finance» idea behind the financial globalization mantra does not hold up to scrutiny either. Financial globalization allegedly improves institutions and practices in countries with underdeveloped financial markets, leading to a more efficient allocation of resources. While compelling empirical evidence in support of such »indirect benefits « does not exist, the point to emphasize here is that the alleged gains do not require hot money for their delivery anyway.

Essentially, a CAM regime can be designed that refocuses the activities of central banks (and sovereign wealth funds; SWFs) is such a way as to capture the alleged microeconomic efficiency gains - while avoiding the premium that is attached to self-insurance. Properly designed, any microeconomic benefits supposedly arising from hot money flows as the transmitters of foreign expertise may still be obtained even when blocking those very inflows.

In the current "self-insurance « regime (shown on the left-hand side of Figure 4), a typical EME's international investment position (IIP) has low-yielding reserve assets as the main asset category and high-yielding EM assets owned by foreign investors as the main liabilities. This balance sheet composition arises as the EME central bank intervenes in currency markets to contain exchange rate pressures and invests the acquired foreign exchange in reserve assets. In practice, as their capacity for "sterilization " through asset sales is exhausted, central banks typically either issue domestic currency debt instruments or raise banks' reserve requirement ratios. In a narrow (fiscal) sense, there appears to be no cost involved as long as domestic interest rates on these domestic currency liabilities do not exceed interest rates on reserve assets. From a national perspective it is the impact on the IIP as shown in Figure 4 and any related resource transfer that matter. Even as part of the foreign exchange holdings may get transferred to a "Sovereign Wealth Fund «, for investment in somewhat higher yielding foreign assets, the end result is still the same: the EME ends up paying a premium on hot 


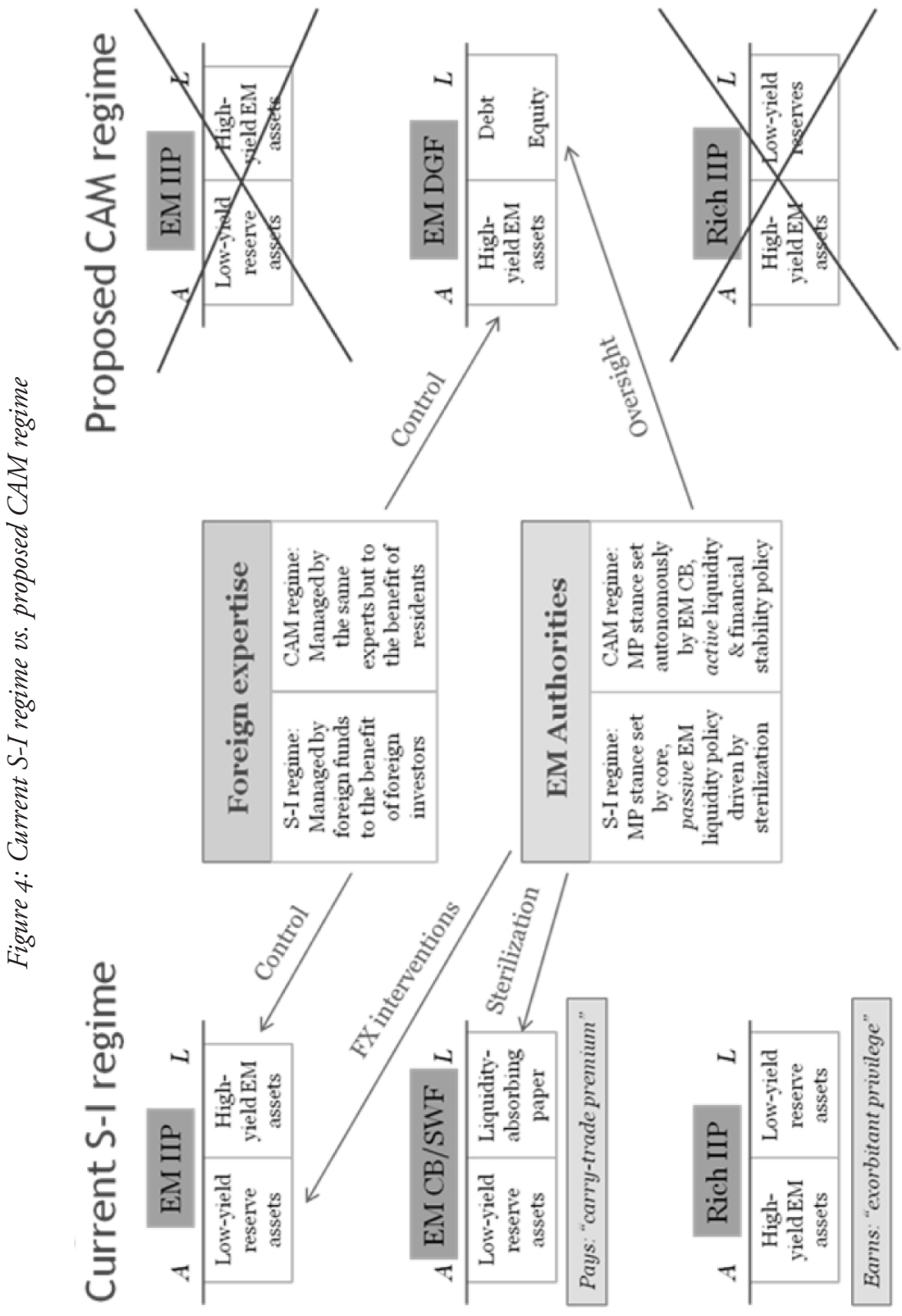


money inflows - the "exorbitant privilege« earned by countries that are the recipients of EMEs' official reserve asset flows (Bibow 2008-9 and 20Iob).

Payment of such a premium on capital inflows may be worthwhile to the extent that those inflows really foster the recipient country's development. The proposed CAM regime merely cuts out the avoidable transfer from poor to rich that is currently captured by means of unwarranted and inherently useless hot money inflows that are recycled as official reserve outflows. As shown on the right-hand side of Figure 4, blocking foreigners from purchasing high-yielding EME assets implies correspondingly reduced purchases of low-yielding reserve assets, and the IIPs of both EMEs and advanced economies will show correspondingly lower gross assets and liabilities. Simultaneously, SWFs are to be turned into "Growth and Development Funds (GDFs), investing in EME rather than advanced country assets. The GDFs thereby replace the allocative role of capital inflows. ${ }^{5}$

Foreign expertise may play various functions in the proposed CAM regime. For instance, the asset management of the GDFs may in principle be left to the very same fund managers that currently steer the foreign portfolio investments on behalf of foreign investors; and, for the sake of the argument, they might even be rewarded for their expertise by unchanged fee structures. Assuming that it makes sense to import their expert services to serve allocative efficiency, the point is that there is no need to import these services on the back of hot money inflows; as footloose drivers of domestic liquidity creation. The potential role for foreign expertise may extend to advising the central bank on monetary policy and the financial stability authorities on financial regulation and supervision. Regarding the GDFs' management, foreign expertise may be partly acquired through services import or direct investments, if that serves industry competition. The key point is that the liabilities structure of the GDFs has domestic ownership, effectively replacing foreign ownership of highyielding EME assets appearing on the liabilities side of the EMEs' IIP under the current self-insurance regime. Under the proposed CAM regime the EME would pay for imported services and any earnings on direct investments, but it would no longer be burdened by the implicit price tag of self-insurance.

The initial equity capital in the GDFs will be to the Treasury (on taxpayers' behalf). Managing the GDFs' liability structures (leverage) might include a role for the central bank and the financial stability authority. While produced at home in any case, liquidity creation can be steered in a more controlled fashion when the central bank enjoys the necessary policy space. The role of the EME authorities thus changes fundamentally. The central bank will no longer passively adapt its policy stance to conditions set at the center and have its liquidity policies driven by sterilization needs. Instead, with decoupling through CAM, the central bank can autonomously determine a monetary policy stance as warranted by

5 In contrast to the scheme proposed here, D'Arista's (1999) scheme of a publically controlled mutual fund continues to permit portfolio capital inflows, which assumes that such inflows are indeed needed. The proposed scheme here is more like a financial market equivalent of a development bank, with the option of inviting foreign expertise in the stock picking. 
domestic requirements. Domestic credit rather than reserve assets are the counterpart to monetary base growth.

The key principles of the proposed CAM regime may then be spelt out. Ideally, only foreign direct investment inflows that match the recipient countries' development goals should be allowed in. Selection may be stricter still in focusing on Greenfield investment only. If M\&A inflows are believed to serve the transfer of foreign knowhow and management skills, a higher than IO\% hurdle may be set so as to block disguised »hot money (portfolio equity) inflows. Beyond concurrent FDI outflows and reasonable reserve accumulation the volume of qualifying FDI inflows determines the maximum size of any safely tolerable current account deficit. In this regard, CAM is similar to self-insurance, a different means toward the same end.

Limiting the current account deficit is first of all a risk containment policy. Reliance on non-FDI inflows represents a hazardous gamble better to be avoided. Hot money-type private capital inflows primarily result in either reduced policy space cum financial fragility risks, or in bloated reserve holdings together with wasteful self-insurance premium payments. Setting up a CAM regime and redesigning SWFs as GDFs avoids these downsides while retaining any potential benefits associated with special expertise that may be in short supply domestically.

It is misleading to associate a current account deficit with increased investment "financed by « foreign saving. Rather, the current account balance is an indicator of a country's intertemporal consumption profile. In practice, a current account deficit may allow increased present consumption, but future consumption will be constrained by the impact of capital inflows on net investment income over time. Of course this trade-off also applies to FDI, but FDI is at least likely to contribute to the recipient country's technological advancement and catching up, so that future incomes will be higher too; whether or not FDI actually means an increased investment rate. If a higher investment rate is the policy goal, this may be more reliably achieved by fostering domestic investment spending directly (which in turn may warrant higher exports to the extent that capital goods are imported). By definition, investment means foregoing present consumption. Ironically, countries that really cannot forego present consumption typically have no access to global finance anyway, and hence must rely on official development aid only.

The current account balance also indicates the balance of growth stimuli a country derives from domestic demand versus net exports. History actually features some rather successful cases of countries running persistent current account surpluses during their fast catching-up phase (Germany, Japan, and China are examples). Section 2 argued that the popularity of the "export-led growth « model with its policy focussation on competitiveness represents a policy response to the hazards of financial globalization - a revealed preference for safety in the periphery that also has systemic implications. Enabling countries to manage domestic demand is a precondition for severing their reliance on export-led growth. CAM may therefore also be an effective way to discourage mercantilist (cum self-insurance) strategies. 
Given the aim of blocking hot money, the regime specifics and peculiar CAM techniques applied should be designed to suit countries' specific structures and circumstances. Quantitative limits, administrative as well as price-based measures targeting financial instruments and transactions all have a role to play in shutting off foreign financing options of households and corporations for domestic activities and containing foreigners' engagements beyond FDI and trade. Corporate and personal income tax codes too may be used for this purpose, as may be the regime of financial regulation and prudential supervision. Macroprudential regulation aims at discouraging business practices and operations that result in excessive systemic risk - a negative externality signaling market failure. EMEs' unchecked exposure to unfettered global finance is a foremost source of such underpriced risks. The proposed CAM regime is thus not distorting efficient markets, but addressing a market failure arising from unchecked financial globalization. As the licensing of parties eligible for conducting or facilitating cross-border financial transactions and their effective supervision are essential for effective CAM, foreign institutions must be required to operate as subsidiaries rather than branches and subject to full host-country regulation and supervision (UN 20IO). Again, foreign expertise (IMF, World Bank, UNCTAD, for instance) may be helpful in all these matters. Domestic shortcomings in these areas are not an argument for but against financial globalization.

The design of CAM regimes does not need to start from scratch. Focusing on the BRICs, the next section investigates how their respective approach to CAM conditioned these countries' exposure and vulnerability to disturbances in global finance, especially during the global crisis and subsequent recovery. The aim is to identify CAM techniques that may serve to shield countries from instabilities in global finance and enlarge their policy space.

\section{The case of the BRICs}

The BRICs cover the whole spectrum of approaches to CAM, with China at one end representing tight regulation, the Russian Federation at the opposite end representing extensive liberalization, and India and Brazil as intermediate cases. Following a period of appreciation against the US dollar, the Brazilian real, Russian ruble and Indian rupee came under severe pressure in 2008 (Figure 5). Renewed strengthening then started in mid 2009. In the Chinese renminbi's (RMB) case, gradual appreciation against the dollar, which had begun with the 2005 exchange rate regime reform, was halted in mid 2008. Holding steady during the crisis, the RMB resumed gradual appreciation in late 20Io. In real effective terms the BRICs have broadly appreciated vis-à-vis the G3 currencies since I994. Currency trends for Brazil and Russia exhibit much more volatility than those for China and India (Figure 6). 
Figure 5: Global financial crisis and BRIC currencies

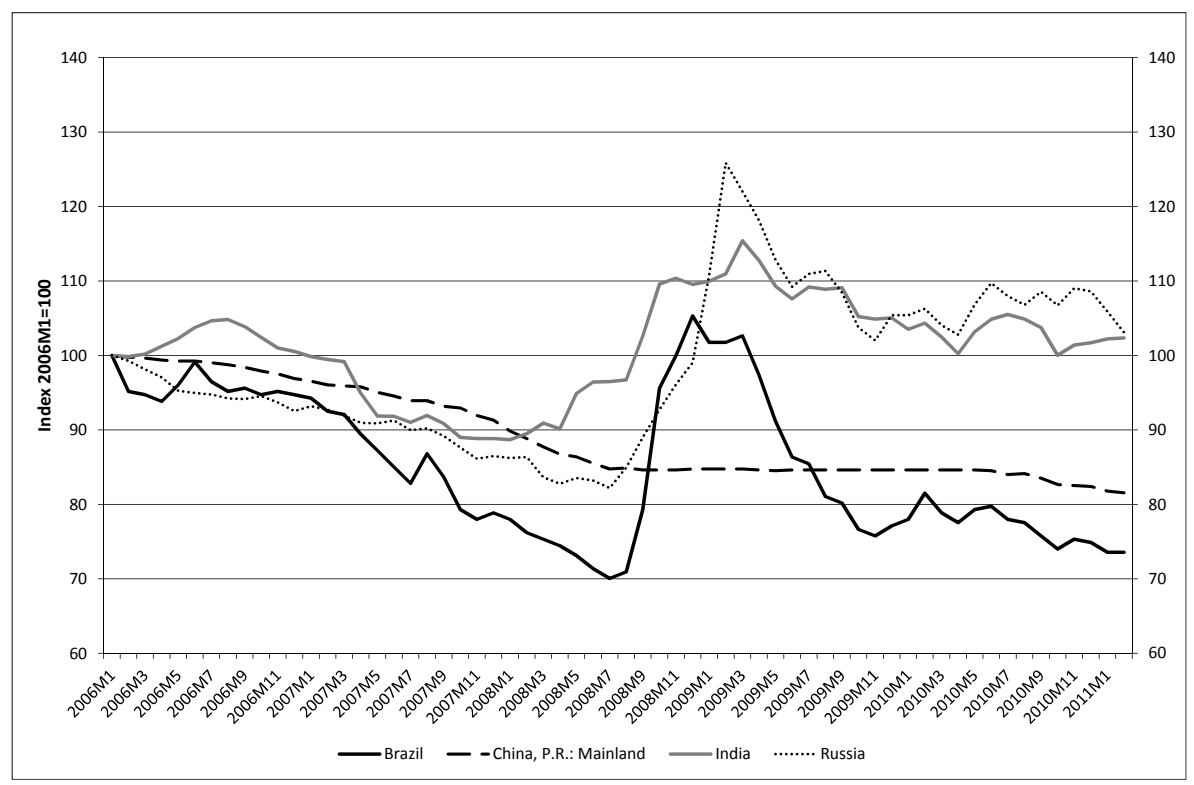

Note: A rising index indicates nominal exchange rate depreciation versus the US dollar.

Source: IMF IFS

The remainder of this section discusses the BRICs' policies regarding their capital accounts and their respective experiences in the global crisis. Table I provides summary statistics on their external positions. Standard measures of financial openness (see Lane/Milessi-Ferreti 2007, Chinn/Ito 2006 and 2008, IMF 2007a) are of limited use. For instance, de facto openness as measured by countries' gross international investment position (IIP) appears to be similar for Brazil and China. Their contrasting net IIPs, which largely reflect the course of their respective current account position over time, and composition of external assets and liabilities, imply different degrees of vulnerability though. The analysis here highlights the composition of capital flows. The hypothesis is that a country's vulnerability and policy space depend on whether its CAM regime effectively contains non-FDI financial flows. While no precise measurement of the costs of self-insurance is attempted, a proxy measure of the implicit self-insurance price tag based on the differential between quasi-yields on foreign assets and liabilities is put forward. 
Figure 6: Real effective exchange rates, $G 3$ and BRICs

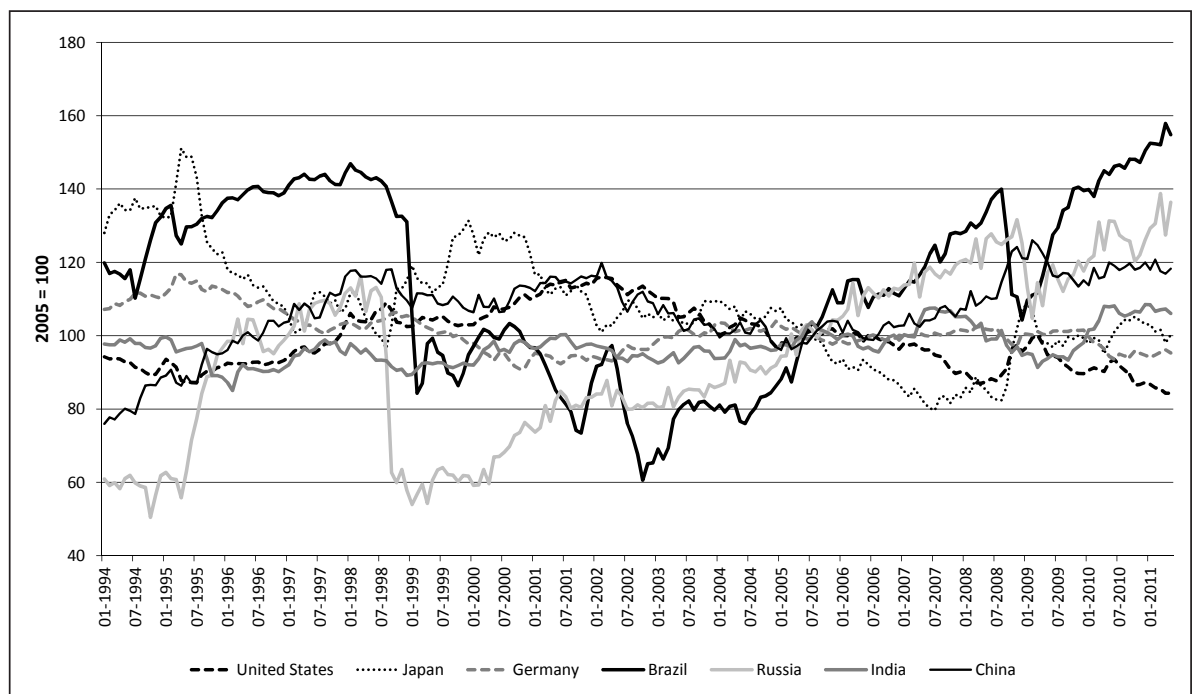

Notes: Broad indices of real (CPI-based) effective exchange rates. A rising index indicates real appreciation.

\section{Source: BIS}

Table I: BRICs and financial openness

\begin{tabular}{|c|c|c|c|c|c|c|c|c|c|c|c|c|}
\hline & \multicolumn{6}{|c|}{ Brazil } & \multicolumn{6}{|c|}{ China } \\
\hline & $\begin{array}{l}\text { IIP, } \\
\text { gross }\end{array}$ & $\begin{array}{l}\text { IIP, } \\
\text { net }\end{array}$ & $\begin{array}{l}\text { Reser- } \\
\text { ves }\end{array}$ & CA & $\begin{array}{l}\text { In- } \\
\text { come }\end{array}$ & $\begin{array}{l}\text { Yield- } \\
\text { diff }\end{array}$ & $\begin{array}{l}\text { IIP, } \\
\text { gross }\end{array}$ & $\begin{array}{l}\text { IIP, } \\
\text { net }\end{array}$ & $\begin{array}{l}\text { Reser- } \\
\text { ves }\end{array}$ & CA & $\begin{array}{l}\text { In- } \\
\text { come }\end{array}$ & $\begin{array}{l}\text { Yield- } \\
\text { diff }\end{array}$ \\
\hline 1990 & & & & -0.75 & -2.29 & & & & & 3.07 & 0.27 & \\
\hline 1991 & & & & -0.33 & -2.17 & & & & & 3.24 & 0.21 & \\
\hline 1992 & & & & 1.43 & -1.87 & & & & & 1.31 & 0.05 & \\
\hline 1993 & & & & 0.00 & -2.16 & & & & & -1.89 & -0.21 & \\
\hline 1994 & & & & -0.19 & -1.52 & & & & & 1.24 & -0.19 & \\
\hline 1995 & & & & -2.36 & -1.44 & & & & & 0.22 & -1.62 & \\
\hline 1996 & & & & -2.77 & -1.45 & & & & & 0.85 & -1.45 & \\
\hline 1997 & & & & -3.50 & -1.88 & & & & & 3.88 & -1.16 & \\
\hline 1998 & & & & -4.02 & -2.33 & & & & & 3.09 & -1.63 & \\
\hline 1999 & & & & -4.43 & -3.29 & & & & & 1.95 & -1.34 & \\
\hline 2000 & & & & -3.77 & -2.78 & & & & & 1.71 & -1.22 & \\
\hline 2001 & 86.67 & -47.93 & 6.49 & -4.20 & -3.57 & -3.13 & & & & 1.31 & -1.45 & \\
\hline 2002 & 91.23 & -46.09 & 7.56 & -1.53 & -3.64 & -3.34 & & & & 2.44 & -1.03 & \\
\hline 2003 & 97.38 & -49.06 & 8.87 & 0.75 & -3.34 & -2.89 & & & & 2.80 & -0.48 & \\
\hline 2004 & 89.36 & -44.73 & 7.95 & 1.76 & -3.08 & -3.16 & 82.11 & 14.53 & 32.25 & 3.55 & -0.18 & -1.49 \\
\hline 2005 & 73.36 & -35.57 & 6.04 & 1.57 & -2.92 & -4.12 & 90.60 & 18.32 & 36.84 & 7.13 & 0.47 & -0.30 \\
\hline 2006 & 77.42 & -33.73 & 7.85 & 1.25 & -2.51 & -2.89 & 101.02 & 23.60 & 39.84 & 9.34 & 0.56 & -0.53 \\
\hline 2007 & 94.43 & -40.29 & 13.20 & 0.11 & -2.14 & -1.32 & 104.29 & 34.00 & 44.28 & 10.64 & 0.74 & -1.23 \\
\hline 2008 & 67.22 & -17.35 & 11.85 & -1.72 & -2.48 & -4.61 & 97.78 & 33.05 & 43.50 & 9.65 & 0.92 & -0.68 \\
\hline 2009 & 98.74 & -38.48 & 15.15 & -1.54 & -2.14 & -2.08 & 102.28 & 36.55 & 49.21 & 5.96 & 0.87 & -0.85 \\
\hline
\end{tabular}




\begin{tabular}{|c|c|c|c|c|c|c|c|c|c|c|c|c|}
\hline & \multicolumn{6}{|c|}{ India } & \multicolumn{6}{|c|}{ Russia } \\
\hline & $\begin{array}{l}\text { IIP, } \\
\text { gross }\end{array}$ & $\begin{array}{l}\text { IIP, } \\
\text { net }\end{array}$ & $\begin{array}{l}\text { Reser- } \\
\text { ves }\end{array}$ & $C A$ & $\begin{array}{l}\text { In- } \\
\text { come }\end{array}$ & $\begin{array}{l}\text { Yield- } \\
\text { diff }\end{array}$ & $\begin{array}{l}\text { IIP, } \\
\text { gross }\end{array}$ & $\begin{array}{l}\text { IIP, } \\
\text { net }\end{array}$ & $\begin{array}{l}\text { Reser- } \\
\text { ves }\end{array}$ & CA & $\begin{array}{l}\text { In- } \\
\text { come }\end{array}$ & $\begin{array}{l}\text { Yield- } \\
\text { diff }\end{array}$ \\
\hline 1990 & & & & -2.16 & -1.00 & & & & & & & \\
\hline 1991 & & & & -1.48 & -1.38 & & & & & & & \\
\hline 1992 & & & & -1.54 & -1.34 & & & & & & & \\
\hline 1993 & & & & -0.66 & -1.31 & & & & & & & \\
\hline 1994 & & & & -0.52 & -1.10 & & 10.70 & 5.37 & 2.35 & 2.83 & -0.66 & \\
\hline 1995 & & & & -1.51 & -1.02 & & 14.08 & 4.20 & 5.49 & 2.22 & -1.08 & \\
\hline 1996 & 41.37 & -21.40 & 7.08 & -1.57 & -0.86 & -0.19 & 13.07 & 1.76 & 3.91 & 2.77 & -1.39 & \\
\hline 1997 & 38.87 & -19.14 & 7.05 & -0.70 & -0.83 & -0.52 & 16.36 & 0.15 & 4.39 & -0.02 & -2.15 & \\
\hline 1998 & 40.30 & -18.56 & 7.68 & -1.61 & -0.85 & -0.44 & 20.47 & -1.61 & 4.51 & 0.08 & -4.35 & \\
\hline 1999 & 40.94 & -16.89 & 8.50 & -0.71 & -0.81 & -0.77 & 26.79 & 2.20 & 6.36 & 12.57 & -3.94 & \\
\hline 2000 & 41.81 & -15.83 & 8.92 & -0.96 & -1.02 & -1.32 & 166.71 & 24.85 & 10.77 & 18.04 & -2.59 & -4.33 \\
\hline 2001 & 44.59 & -14.25 & 11.28 & 0.29 & -0.84 & -0.58 & 154.96 & 14.32 & 11.95 & 11.07 & -1.38 & -2.50 \\
\hline 2002 & 48.42 & -11.64 & 14.64 & 1.37 & -0.76 & -1.22 & 156.40 & 10.77 & 13.85 & 8.44 & -1.91 & -2.91 \\
\hline 2003 & 51.27 & -7.77 & 18.06 & 1.47 & -0.82 & -2.08 & 155.65 & 0.91 & 17.88 & 8.23 & -3.06 & -4.00 \\
\hline 2004 & 54.79 & -6.26 & 20.57 & 0.11 & -0.59 & -1.35 & 139.37 & -1.80 & 21.07 & 10.07 & -2.16 & -2.99 \\
\hline 2005 & 50.59 & -5.86 & 18.56 & -1.27 & -0.82 & -2.26 & 139.36 & -4.12 & 23.86 & 11.08 & -2.48 & -3.26 \\
\hline 2006 & 57.59 & -6.57 & 19.51 & -1.02 & -0.69 & -1.42 & 151.70 & -3.89 & 30.68 & 9.56 & -2.97 & -3.62 \\
\hline 2007 & 64.80 & -6.49 & 23.90 & -0.70 & -0.57 & -0.90 & 179.68 & -11.56 & 36.84 & 5.98 & -2.37 & -1.95 \\
\hline 2008 & 59.51 & -6.81 & 20.30 & -2.46 & -0.26 & 0.18 & 106.02 & 15.33 & 25.57 & 6.22 & -2.94 & -8.54 \\
\hline 2009 & 71.53 & -9.94 & 22.92 & -2.15 & -0.53 & -0.41 & 170.46 & 9.61 & 35.67 & 4.01 & -3.21 & -4.36 \\
\hline
\end{tabular}

Notes:

International Investment Position (IIP), gross = sum of external assets and external liabilities (\% GDP) International Investment Position (IIP), net = external assets minus external liabilities (\% GDP)

Reserves $=$ official reserve asset flows $(\%$ GDP $)$

$C A=$ current account balance $(\% \mathrm{GDP})$

Income $=$ income balance on current account (\% GDP)

Yielddiff $=$ differential of quasi yields, estimated as income on external assets or external liabilities respectively

Source: IMF IFS

\section{China}

Alongside reforming its exchange rate regime (creating a de facto dollar peg, officially a managed float), China established conditional current account convertibility and began opening its capital account in 1994; albeit gradually with FDI inflows only at first and FDI projects requiring approval by local governments. Non-FDI inflows required approval by the People's Bank of China ( $\mathrm{PBoC}$ ) and any receipts had to be deposited in a specified account and could only be used for specified expenditures; conversion into RMB being generally disallowed. Since joining the WTO in December 20or permission was granted to some foreign banks for undertaking business in RMB, to domestic investors for investing their own foreign exchange in B-shares, to qualified foreign institutional investors for investing in 
China's financial markets, and to insurance companies for using their own foreign exchange to invest internationally.

As the buildup of reserves soared in the mid 20oos China applied "measures to promote balanced capital inflows and outflows" (PBoC 2008). This meant tightening controls on unwelcome inflows such as foreign banks' external borrowing while facilitating certain private outflows, including firms' overseas direct investments and banks' and other qualified institutional investors' overseas portfolio investments (Yu 2008). China's CAM is to be seen within the context of a tightly regulated bank-based financial system, in which foreign banks continue to play only a marginal role (McMahon 20IO). The banking system was characterized by fragilities until the mid 200os, when key banks were re-capitalized. Left unscathed by the global financial crisis, China's key banks rank among the world's largest today.

With Hong Kong traditionally serving as a laboratory (Oster/McMahon/Lauricella 20IO, Yue 2OII), offshore RMB trading was recently expanded to the US through the Bank of China (Wei 20II). While fostering the trade-related use of RMB seems to be the primary aim, other recent initiatives concern the management of capital outflows. Export companies may now keep more of their foreign exchange earnings offshore for investment purposes. And a pilot project in the city of Wenzhou permits individuals to invest directly overseas in excess of the general limit of \$50,000 per year (Anderlini 20II, Cookson 20IIa and b).

\section{Figure 7: Inward FDI flows dominate China's capital account}

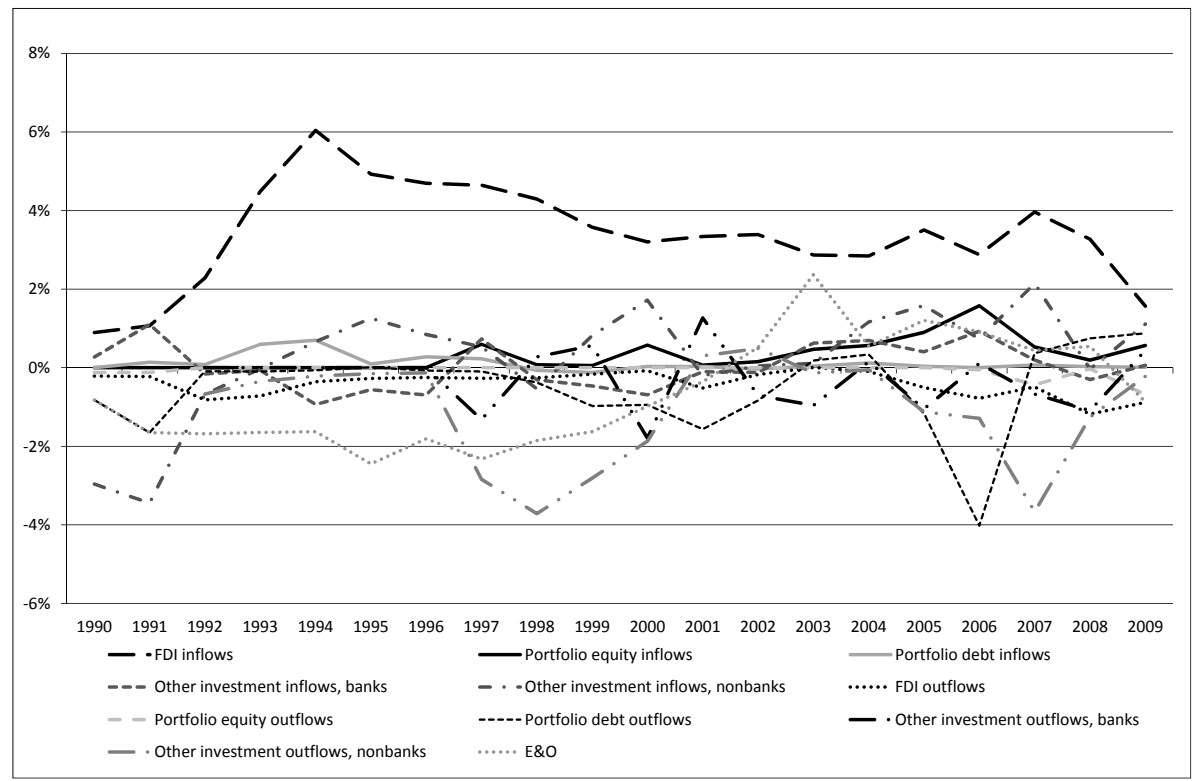

Note: All flows in per cent of GDP.

Source: IMF IFS 
Figure 7 shows that inward FDI flows have dominated the capital account - in line with the aims of China's CAM regime. That portfolio equity and other investment inflows gained during the 2000 slobal bonanza may partly reflect cautious liberalization, but also circumvention of controls. The fact that the »errors \& omissions « category changed sign (or direction, unmeasured outflows turning into inflows) in 2002 may perhaps be seen as a sign of the latter. According to the State Administration of Foreign Exchange illegal speculative capital inflows contributed $\$ 28.9$ bn per year on average over the last decade, equivalent to around 9 per cent of the increase in China's currency reserves (Dyer 20II).

\section{Figure 8: Composition of China's international balance sheet}

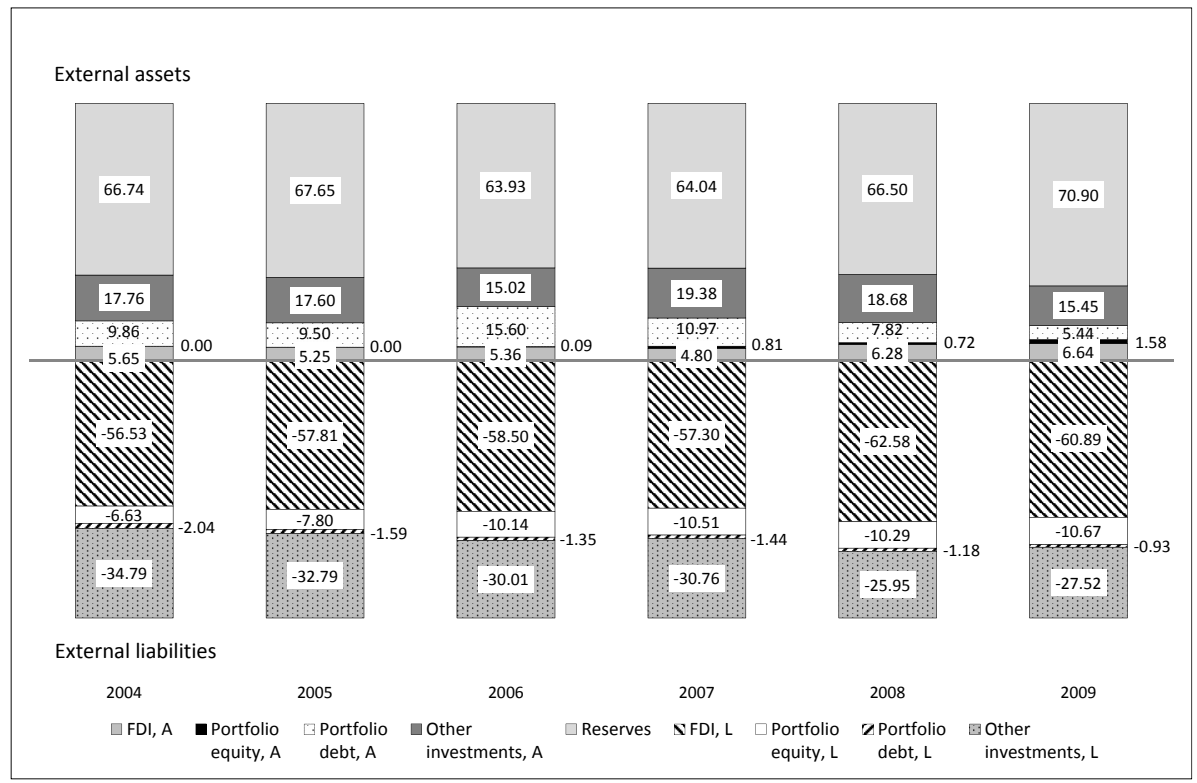

Note: As percentages of total external assets or liabilities.

\section{Source: IMF IFS}

Based on the historical cost approach, China's net creditor position reached USD I.8tr or 37 per cent of GDP by 2009. ${ }^{6}$ At just over Ioo per cent of GDP in that year the size of its gross international balance sheet remains relatively small (compared to advanced countries). External assets consist predominantly of reserve assets while a sizeable inward FDI stock is the largest liability item (Figure 8 ). ${ }^{7}$ Reflecting the dominance of low-yielding reserve assets,

6 Official data on China's IIP is only available from 2004 onwards. Estimates show that at market value China's net IIP was only 9 per cent of GDP in 2007 compared to a value of 30 per cent at historical cost (Ma/Haiwen 2009).

7 China's US Treasury holdings are estimated at \$1,I6obn (Mackenzie 20II). 
estimates of "quasi-interest rates" (assuming that income flows consist of investment income only) suggest that the income yield of China's external liabilities exceeds the income yield of its assets (as indicated by a negative yield differential ("yielddiff") in Table I). China’s income balance on current account only turned positive in 2004 .

\section{Figure 9: Sources of China's reserve holdings}

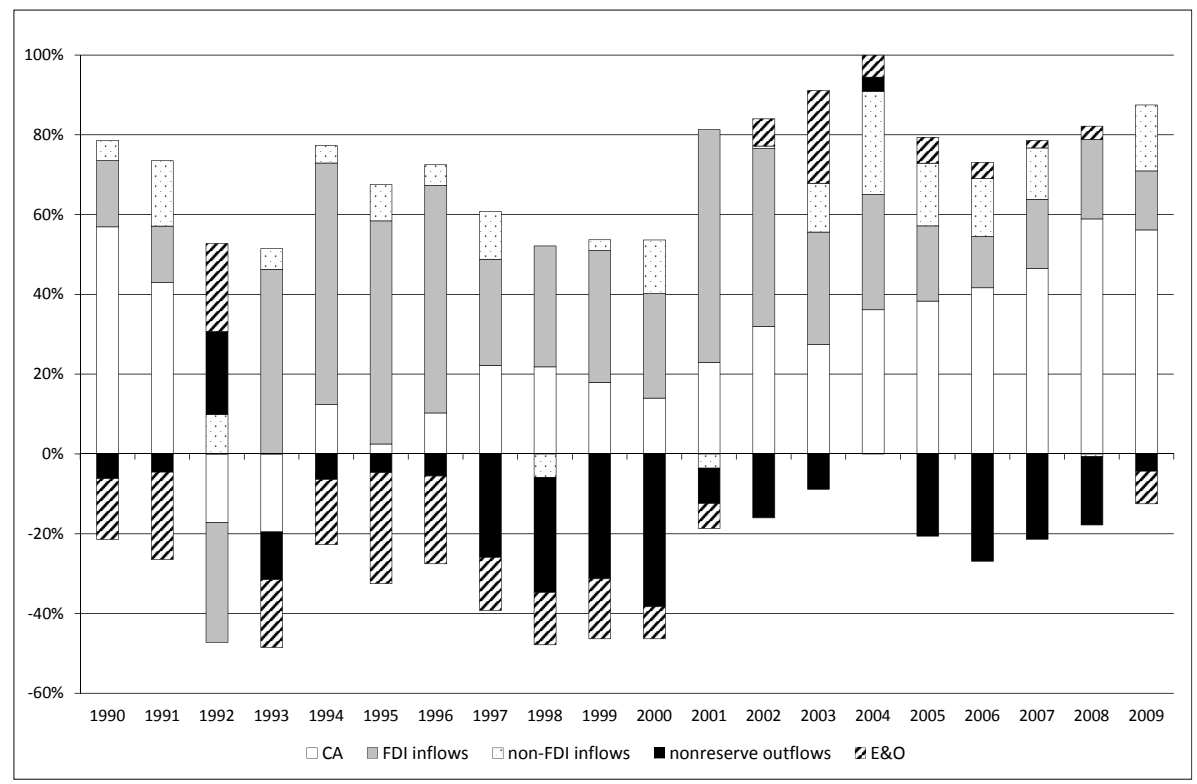

Source: IMF IFS

Another way of looking at the matter is to decompose the sources of China's huge official reserve holdings, exceeding $\$ 3$ tr by the spring of 201 . Figure 9 shows that inward FDI flows provided the most important source during the I990s while persistent current account surpluses took over that role in the 20oos. Arguably, containing exchange pressures was instrumental in sustaining China's position as a principal destination for FDI, using the country as their export base. Since 2003 China has also become a weighty source of outward FDI flows, soaring to roughly half the size of inward flows in 2008 and 2009 (UNCTAD 2006 and 20IO). The rise of Chinese multinational corporations is concentrated in services (export-support business) and resources and dominated by state-owned enterprises under the control of the central government (Zhang 2009).

Openness and reliance on exports made China vulnerable to the "Great Trade Collapse«, but not much damage was suffered through financial linkages. China swiftly responded to the crises by launching a RMB 4tn (USD 586bn) macroeconomic stimulus package in November 2008, amounting to some I4 per cent of 2008 GDP (Yu 2008). As a result, China emerged quickly from the crisis, as a key engine of the global recovery. 
The size and composition of China's capital inflows and its international balance sheet attest the effectiveness of its CAM regime, which also shielded China from the global financial shock and contributed to creating the policy space that allowed China to successfully counter the crisis. China surely was exceptional in keeping its currency stable to the dollar throughout the crisis. Only minor outflows from its reserve holdings were recorded during some months at the peak of the crisis. More corroborating evidence as to the effectiveness of China's CAM regime arises from the fact that China's monetary policy stance enjoys considerable independence from the US despite the RMB's dollar-link (Ma/McCauley 2007).

But other factors too played a role in enlarging China's policy space. One important factor is that China has maintained very low inflation rates (at times deflation) while pursuing growth-oriented monetary policies; incomes policies have kept wages and productivity growth aligned (Flassbeck 2005). China thereby avoided larger interest rate differentials and correspondingly stronger incentives for hot money capital inflows. China's favorable fiscal position at the outset of the GFC, not unrelated to its external surplus, offered the fiscal space to launch a large stimulus package. ${ }^{8}$ Export surpluses had ballooned in the years prior to the crisis, but China has clearly started to rebalance away from export dependence since (Bibow 20IOc).

Finally, despite the country's huge foreign reserves, China's CAM regime has helped to keep the costs of self-insurance at bay. Since only a small part of China's reserves was sourced from hot money inflows, the wasteful resource transfer resulting from inherently useless inflows was correspondingly small as well. China's CAM regime may be a model for other EMEs to follow.

\section{India}

The balance of payments crisis of I99I marks a watershed in India's economic policies. The crisis prompted an IMF structural adjustment program that included liberalization of the current and capital accounts. Prior to the crisis official and private debt inflows provided the main sources of external finance. Since the crisis India has aimed at blocking debt inflows, especially short-term ones. By contrast, India has gradually opened up to equity inflows, both FDI and portfolio, and more recently also began to relax restrictions on FDI outflows by Indian corporations. Portfolio inflows are managed through a "Foreign Institutional Investment« (FII) framework that requires registry of eligible foreign investors.

As aspired, portfolio equity inflows were a multiple of portfolio debt inflows in the 200os. ${ }^{9}$ Other debt inflows include bank deposits held by »Nonresident Indians (NRIs) and „External Commercial Borrowings« (ECBs) by corporations, and remain highly managed.

8 The stimulus included government spending and a vast lending program undertaken by stateowned banks (the latter representing implicit fiscal legacy risks arising from nonperforming loans).

9 IMF IFS do not include information on portfolio debt flows in the balance of payments statistics but changes in India's IIP, unless reflecting valuation effects, imply debt flows in the order of 20 per cent of equity flows in the 2000s. 
Tight ceilings also apply to banks' overseas borrowing and lending. Restrictions on capital outflows by institutional investors and residents were eased somewhat in recent times (see Mohan 2008, Sen Gupta 20I0, Shah/Patnaik 2008 and 20II, Gopinath 20II).

Figure Io: Rise in more volatile capital inflows in India's capital account

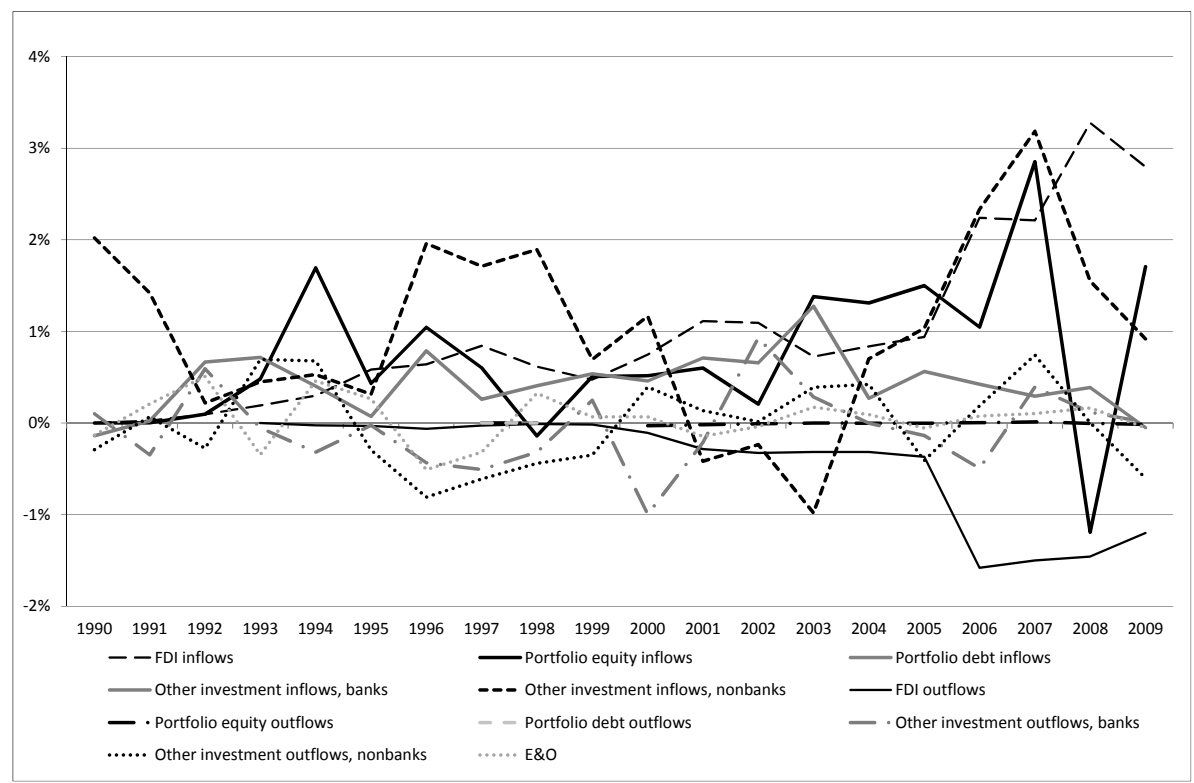

Note: All flows in per cent of GDP. Data for portfolio debt flows is not available.

\section{Source: IMF IFS}

Figure Io shows that while FDI inflows have been on the rise since 2005 the same also holds for portfolio equity and other (nonbank) investment types; with non-FDI inflows playing a much larger relative role than in China's case. Underscoring their "hot money« nature, both types have exhibited a rollercoaster behavior in recent years. Figure II shows the sudden reversal in capital flows at the peak of the global financial crisis. Sizeable reserve losses were recorded as the Reserve Bank of India intervened to contain rupee depreciation.

Reserves are India's main external asset category, with outward FDI gaining in prominence in recent years. On the liability side the growing stocks of inward FDI and portfolio equity have gained at the expense of other investment liabilities. India's NIIP is close to negative Io per cent of GDP valued at historical costs (but more adverse at market values). While India's de facto openness appears to be lower than China's, the much larger relative role of China's inward FDI stock is noteworthy. India's greater reliance on hot money inflows involves rising external vulnerabilities and reduced policy space. Interventions partly curtailed rupee appreciation in the years prior to the global crisis, involving self-insurance 
costs arising from excessive non-FDI inflows. Based on estimated quasi-interest rates India has faced an adverse yield differential comparable in magnitude to China's.

\section{Figure II: Crisis impact on India's financial account}

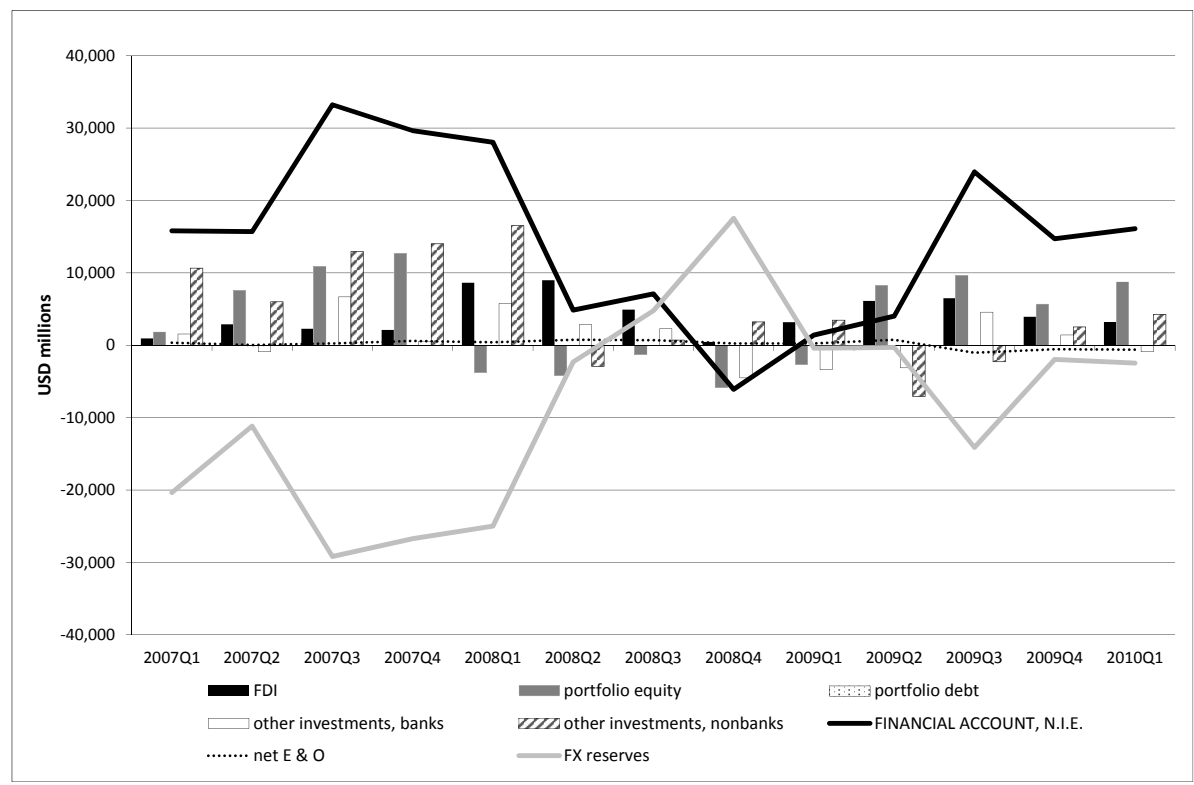

Note: Net flows. Data for portfolio debt flows is not available.

Source: IMF IFS

While India too at first saw its current account balance shift from deficit into surplus in the aftermath of the Asian crises, an external deficit reappeared by 2005, rising quite sharply to 3 per cent of GDP by 20Io. Traditionally, India has a more sizeable trade deficit that is partly offset by remittances. Having been less affected by the trade collapse and given its banks' good health, the Indian economy recovered swiftly from the crisis, supported by a sizeable fiscal stimulus and RBI easing. Resurging capital inflows since mid 2009, driven by portfolio equity and ECBs, have prompted more limited intervention and reserve accumulation this time round. Rupee appreciation accelerated in the final quarter of 20IO, India's current account deficit kept on rising. Overall, the Indian authorities combine greater reliance on non-FDI inflows with greater exchange rate flexibility. Self-insurance and CAM both play a role too. The tolerated rise in the current account deficit features increased limits on ECBs, with stipulations on their use for infrastructure investment purposes and a minimum maturity of five years though. 
Figure I2: India's international balance sheet

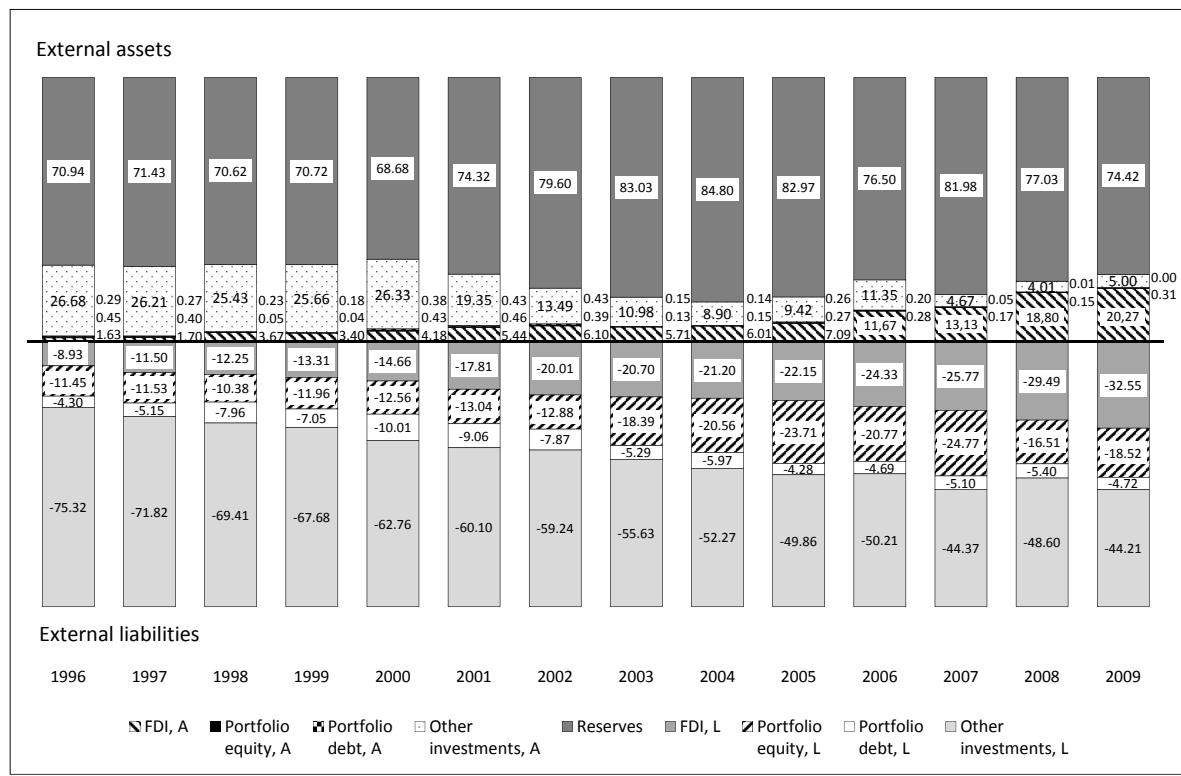

Note: As percentages of total external assets or liabilities.

Source: IMF IFS

\section{Brazil}

The balance of payments crisis of 2002 marked the turnaround in Brazil's current account balance, with surpluses lasting until 2006. A surge in FDI inflows had characterized the pre-crisis era of large current account deficits. At around 2 per cent of GDP since 2002 FDI has continued to represent the largest inflow category, but in 2005 other investment and in 2007 portfolio inflows too increased very strongly.

Brazil had experimented with capital controls earlier in the I990s (see Cardoso/Godfajn 1998, Gacia/Valpassos 1998). Brazil's capital account was largely liberalized in the 2002-09 period, but its banking system, including a significant presence of foreign banks largely organized as subsidiaries, was more tightly supervised than in rich countries. Brazil experienced a brief but sharp sudden reversal in the final quarter of 2008 - with a new incoming flood reaching its shores since 2009. What stands out is that the reversal in bank flows at the peak of the crisis was very mild. In fact, Brazil's banks have not suffered from the financial crisis and have sustained high profitability (Pérez 20II). Apart from currency market interventions the decline in reserves at the peak of the crisis (see Figure I4) also owed to the central bank's setting up of facilities to provide trade finance and support companies' rollover of foreign debt. Despite 


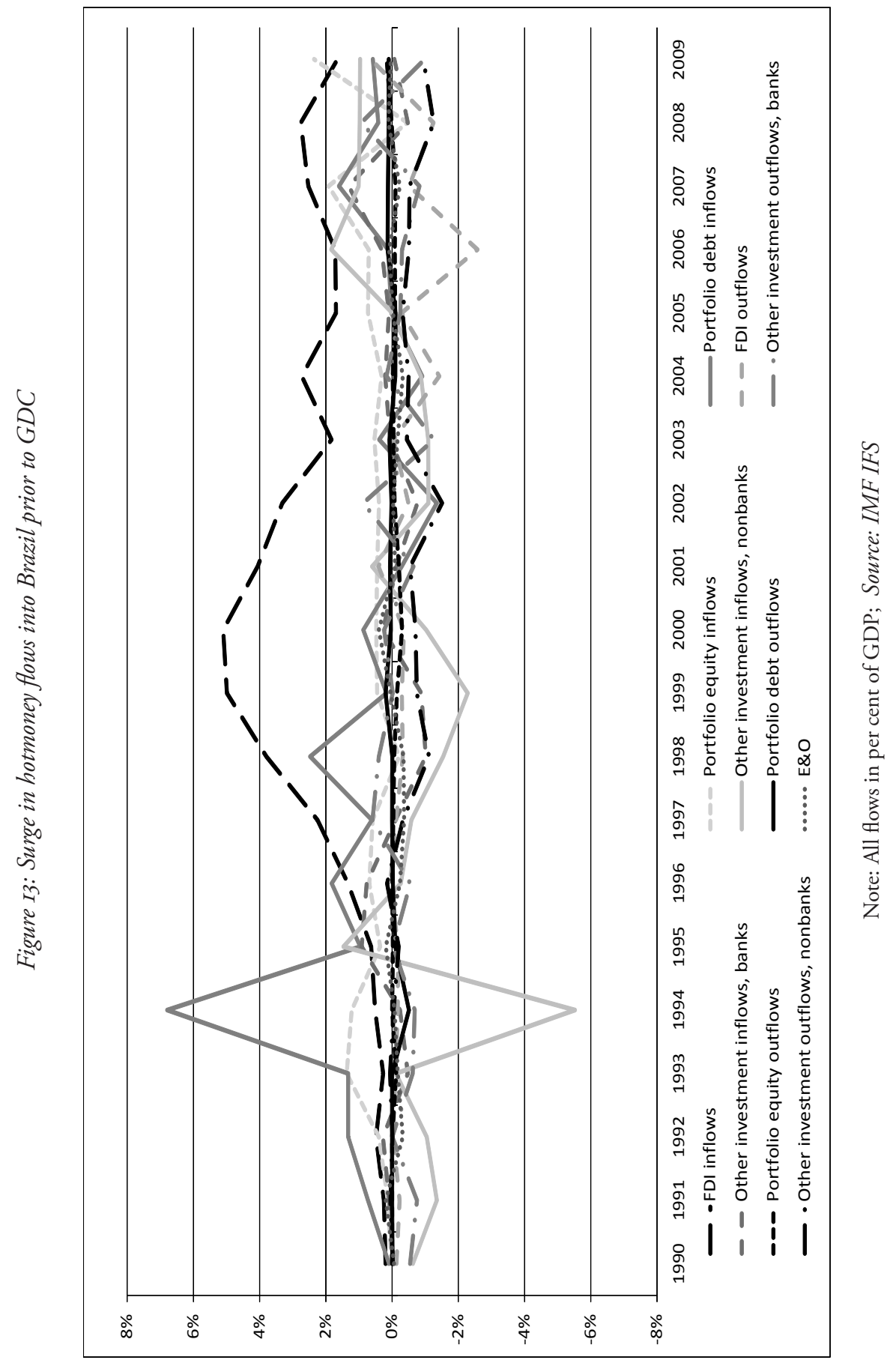


having been severely hit initially by the collapse in trade volumes and commodity prices the strength in domestic demand growth supported by macro policy, including a large role of the Brazilian Development Bank, allowed Brazil's economy to swiftly bounce back, all the more so as China's recovery lent renewed support to commodity prices.

\section{Figure I4: Crisis impact on Brazil's financial account}

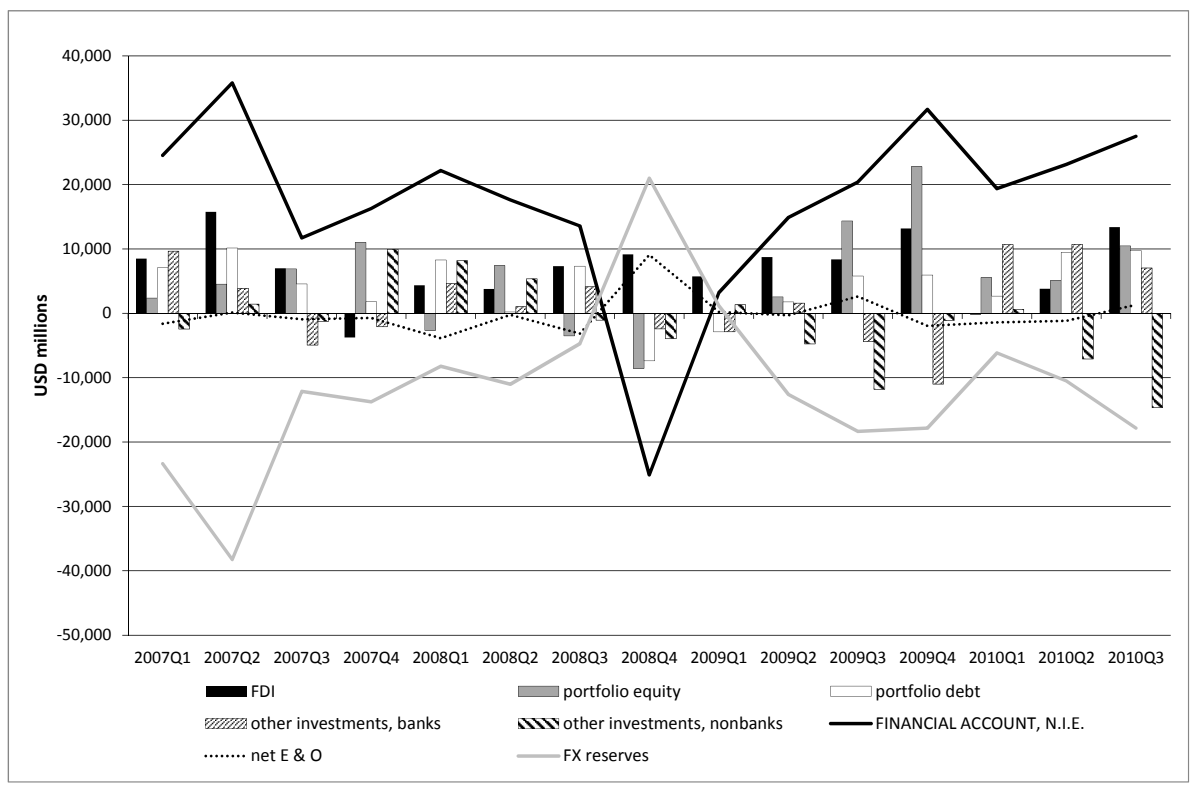

Note: Net flows.

Source: IMF IFS

As capital inflows resurged on the back of the recovery, Brazil introduced a tax on portfolio inflows in October 2009 to counter the real's sharp appreciation. The tax rate initially set at two per cent was later raised to 6 per cent on portfolio debt inflows in the fall of 20I0, and in January $20 I I$ a shortselling ban targeting onshore commercial banks was added to the list of measures designed to stem appreciation (Leahy 20II). As earlier in the I990s, Brazil is once again confronted with the special challenges arising in a country with relatively high inflation and real interest rates, squarely attracting carry trade investors. To be effective, tax rates have to be set at a sufficiently high rate to offset such large differentials. By contrast, monetary tightening only adds fuel to the fire, pushing up the currency and further undermining Brazil's competitiveness. Of course the same holds for monetary easing at the center, which has prompted »currency war» concerns with the Brazilian authorities. ${ }^{10}$

Io Fiscal tightening is suggested as another prudent response to capital inflows. Cuts in housing for the poor and reigning in its development bank illustrate the trade-offs involved. See Leahy and Pearson 2OII. 
Figure I5: Brazil's international investment position

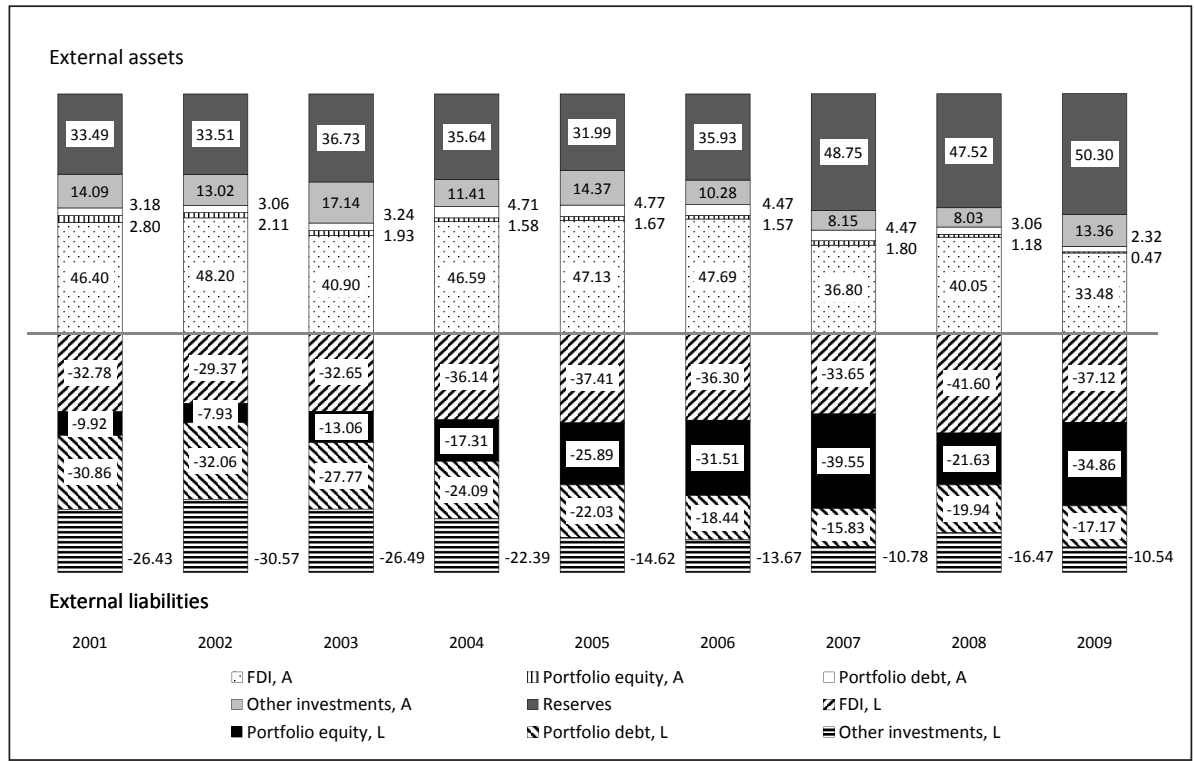

Note: As percentages of total external assets or liabilities.

Source: IMF IFS

At Ioo per cent of GDP Brazil's financial openness appears to be comparable to China's. The much greater role of hot money in Brazil's case suggests greater vulnerabilities. In view of real appreciation and Brazil's deteriorating current account, currency market intervention and reserve accumulation may be judged insufficient. Yet, even at the actual rate of reserve accumulation - as the asset-counterpart to unwarranted capital inflows - Brazil is a clear case in point regarding the costs of recourse to self-insurance. In line with large interest differential the differential in "quasi-yields" estimated for Brazil's external assets and liabilities is particularly adverse, much more so than in China's and India's case (see Table I). In fact, its negative income balance is the dominant contributor to Brazil's current account deficit. Closing the capital account to unwarranted types of capital inflows is the preferable strategy. While banks seem healthy and household leverage low by international standards, very high credit growth rates, rising property prices and household debt service ratios suggest that capital inflows and exchange appreciation feed into domestic financial fragilities.

\section{Russia}

Russia's transition in the I990s was characterized by massive capital flight and crisis in I998 (Loungani/Mauro 2000). While outflows continued after 2000, their composition has featured a rise of FDI by Russian corporations (much in line with rising FDI inflows). 
Since 2002 other investment inflows have also grown strongly and, finally, portfolio equity inflows too surged as Russia scrapped remaining capital controls in July 2006, inviting the global bonanza to reach the country just before the global crisis hit.

Figure I6: Russia - Sizeable outflows paired with volatile inflows

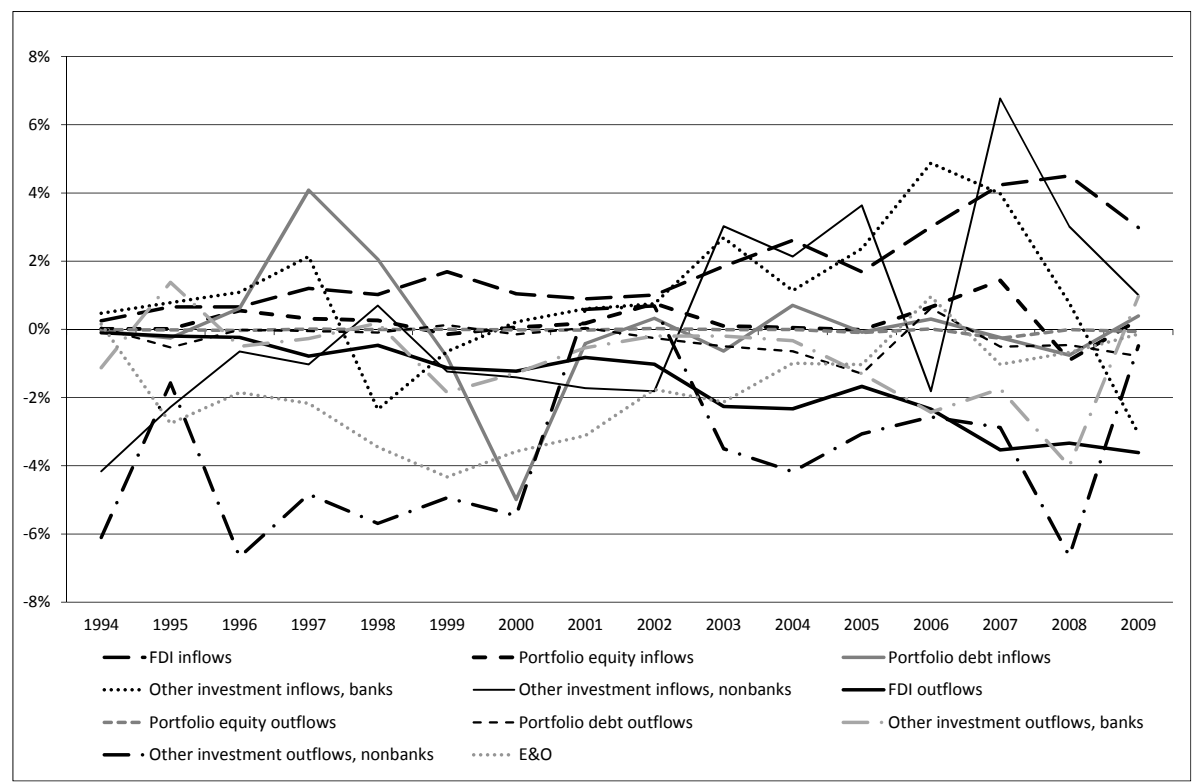

Note: All flows in per cent of GDP.

\section{Source: IMF IFS}

Russia’s current account has been in continuous surplus since the 1998 crisis, surging in the 200os in line with the oil price boom. While Russia's oil stabilization fund mechanism largely absorbed the oil price windfall, a credit-driven boom in domestic demand (with annual credit growth rates in excess of 40 per cent) encouraged by foreign currency borrowing alongside gradual ruble appreciation created important vulnerabilities. Rapid private sector external debt buildup more than offset the decline in external public debt. Heavily exposed to the global deleveraging in banking flows, the sudden reversal after mid 2008 was particularly sharp in Russia's case and especially pronounced in the other investment category. 
Figure 17: Crisis impact on Russia's financial account

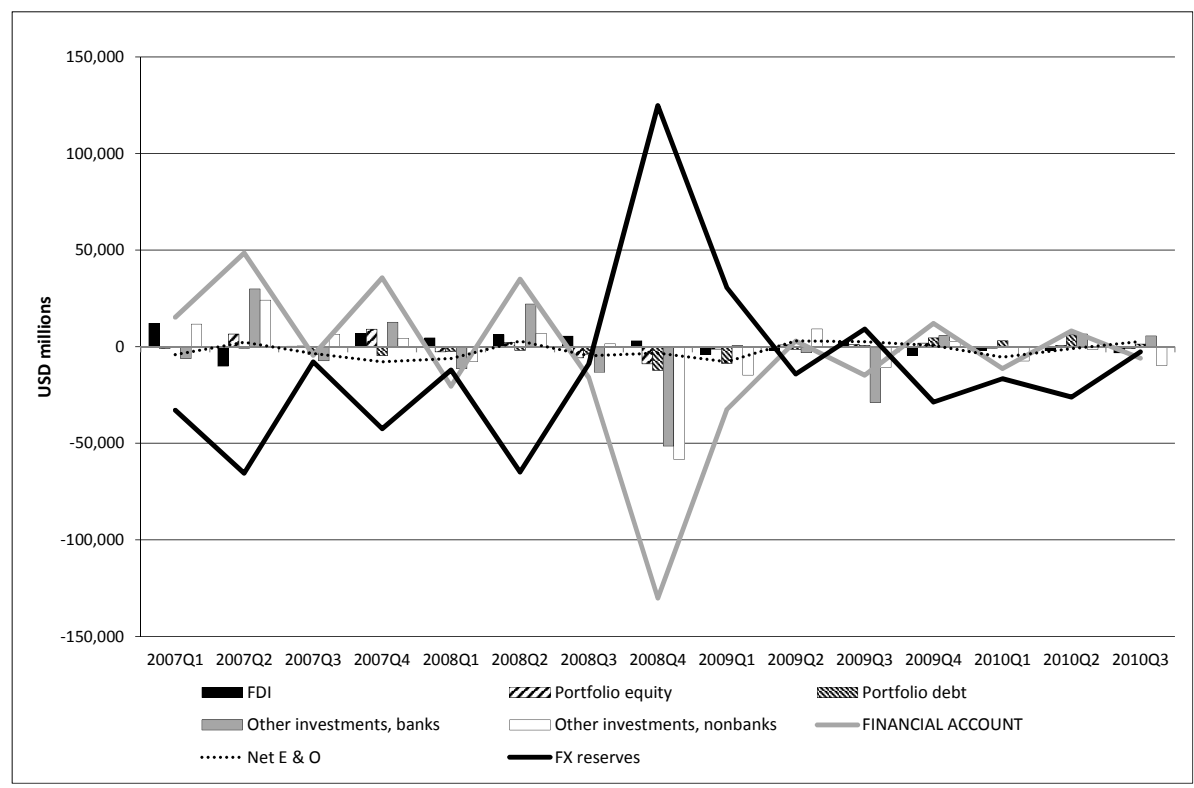

Note: Net flows.

Source: IMF IFS

External assets and liabilities reaching I8o per cent of GDP just before the GFC, Russia is by far the most financially open BRIC country. Despite many years of large current account surpluses its net IIP may be close to zero in 20IO. As low-yielding reserves are the main asset while FDI and portfolio equity represent the main foreign liabilities, Russia's income balance on current account is negative 3 per cent of GDP. The estimated differential in "quasiyields « is even more adverse than in Brazil's case. As Russia does not require foreign saving to "finance« any current account deficit while net FDI flows are close to zero, this indicates sizeable self-insurance costs arising from unwarranted capital inflows.

In summary, while admittedly drawing on a small sample of CAM regimes employed in the BRICs, some tentative conclusions are in order. China's comprehensive CAM regime effectively shielded the country from the external financial shock. The exchange rate was held steady at only minor currency reserve losses. The examples of India, Brazil and Russia underline that financial globalization beyond FDI reduces macro policy space and creates vulnerabilities. Related risks are avoidable and only partly justified by their respective current account position, if at all. It is preferable to block rather than park excessive capital inflows. Compared to CAM, self-insurance is a costly exercise that remunerates foreign investors for unwarranted services. 
Figure I8: Russia's international balance sheet

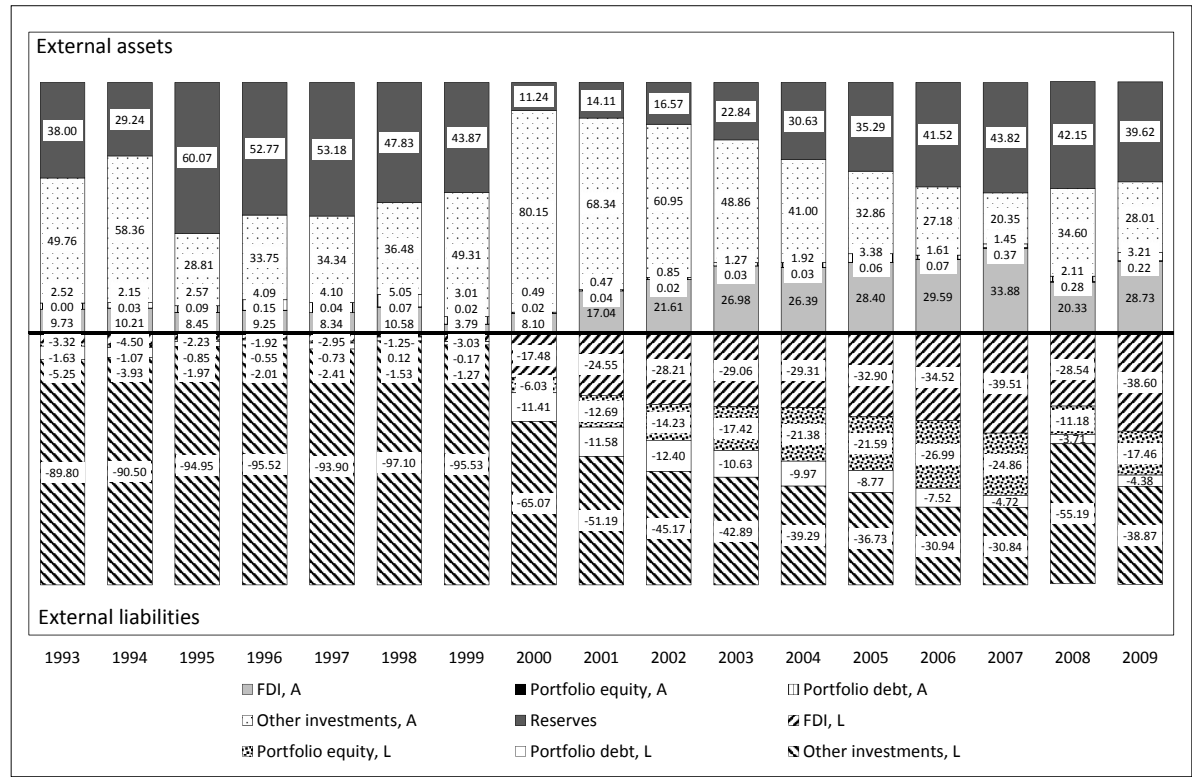

Note: As percentages of total external assets or liabilities.

Source: IMF IFS

\section{Conclusion}

The ideological push for capital account liberalization presupposes a »saving gap " in the developing world to be closed by capital flows. In truth catching-up in EMEs does not even require foreign saving. Certainly tolerating current account deficits beyond (net) FDI inflows is primarily hazardous; as compellingly evidenced by financial crises in EMEs. Limiting current account deficits through currency intervention and reserve accumulation is not costless either. The self-insurance boom of the 2000 s has contributed to the perverse resource transfer from poor to rich. Allowing access to unwarranted hot money flows only to park the destabilizing inflows in low-yielding reserve assets highlights that rent extraction is at the heart of financial globalization - as one aspect of the seemingly paradoxical phenomenon of (net) capital flows from poor to rich. The analysis shows that any indirect benefits attributed to financial globalization as improving efficiency in resource allocation may be »synthesized « by a CAM regime that turns SWFs into GDFs. The first phase of financial globalization was characterized by fragilities and crises originating in EMEs. As defensive macroeconomic policies became en vogue in EMEs in the second phase, fragilities shifted to the core of 
the global financial system (still enjoying rent extraction engineered through financial globalization). The experience calls for a fundamental policy reorientation: globalization needs to be managed, especially capital flows. Financial globalization beyond FDI flows is simply not advisable.

With proper reform of the international monetary and financial order unlikely at this point, CAM offers three major advantages to developing countries. First, it creates macro policy space by decoupling from the monetary policy stance set at the center. Second, it avoids financial vulnerabilities arising from unfettered global finance. Third, it avoids the costs associated with bulging reserve holdings sourced from unwarranted capital inflows. For the world at large there is the additional advantage that CAM reduces the incentive for defensive macroeconomic policies on the part of the periphery - and thereby also its systemic counterpart: the need for "overspending « by the lead country.

Studying the BRICs broadly covers the spectrum of CAM regimes in place. CAM contributed to China's resistance to and ability to swiftly overcome the GFC, an open capital account to Russia's heightened vulnerability and inability to overcome the crisis by domestic means. Traditionally cautious with regard to global finance, India has increased its external vulnerability in recent times through liberalization and toleration of larger current account deficits. As an especially attractive hot money destination given relatively high inflation and real interest rates, Brazil struggles moving in the opposite direction. Going forward, studying country experiences can inform the choice of techniques that work best under certain circumstances. Properly designed CAM regimes can be made effective if a serious attempt were made. ${ }^{\text {II }}$

\section{References}

Abdelal, R. (2007): Capital Rules: The Construction of Global Finance. Harvard University Press. Anderlini, J. (20II): Chinese city allows personal investing abroad, in: Financial Times, Io January.

Bibow, J. (2008): The international monetary (non-)order and the rglobal capital flows paradoxı, in: Hein, E., Spahn, P., Niechoj, T., Truger, A. (eds.), Finance-led Capitalism?, Marburg: Metropolis, 219-48.

Bibow, J. (2008-9): Insuring against private capital flows: Is it worth the premium? What are the alternatives?, in: International Journal of Political Economy, 37(4), 5-30.

Bibow, J. (2009): Keynes on Monetary Policy, Finance and Uncertainty: Liquidity Preference Theory and the Global Financial Crisis, London and New York: Routledge.

Bibow, J. (20I0a): Bretton Woods 2 is dead, long live Bretton Woods 3?, Levy Economics Institute, Working Paper no. 597, May.

Bibow, J. (2OIOb): Global imbalances, the US dollar, and how the crisis at the core of global finance spread to self-insuring emerging market economies, in: Intervention, 325-59.

II See also Coelho and Gallagher 20I0, David 2007 and 2008, Edison and Reinhart 200I, Epstein, Grabel and Jomo 2004, Magut, Reinhart and Rogoff 201 . 
Bibow, J. (20IOc): How to sustain the Chinese economic miracle? The risk of unraveling the global rebalancing, forthcoming in: The Chinese Economy.

BIS (20II): BIS Annual Report, Bank for International Settlement, Basel, http://www.bis.org/ publ/arpdf/arzorie.pdf

Borio, C., Disyatat, P. (20II): Global imbalances and the financial crisis: Link or no link?, BIS Working Paper, No. 346, May.

Cardoso, E., Godfajn, I. (1998): Capital flows to Brazil: The endogeneity of capital controls, in: IMF Staff Papers, no. 45, 16I-202.

Carvalho, B., Garcia, M. (2006): Ineffective controls on capital inflows under sophisticated financial markets: Brazil in the I990s, NBER Working Paper I2283, June.

Chinn, M., Ito, H. (2006): What matters for financial development? Capital controls, institutions and interactions, in: Journal of Development Economics, 81, I63-92.

Chinn, M., Ito, H. (2008): A new measure of financial openness, in: Journal of Comparative Policy Analysis: Research and Practice, IO(3), 309-22.

Coelho, B., Gallagher, K.P. (20I0): Capital controls and $2 \mathrm{I}^{\text {st }}$ century financial crises: Evidence from Colombia and Thailand, PERI, Working Paper no. 213.

Combes, J.L., Kinda, T., Plane, P. (20II): Capital flows, exchange rate flexibility, and the real exchange rate, IMF Working Paper.

Cookson, R. (20Ira): HK price differentials create renminbi openings, in: Financial Times, Io January.

Cookson, R. (20Irb): China eases corporate rules on renminbi, in: Financial Times, I3 January.

D'Arista, J. (1999): Reforming the privatized international monetary and financial architecture, financial markets and society, Financial Markets Center, Philomont, VA, November.

David, A.C. (2007): Revisiting price-based capital account regulations in a sophisticated emerging market, in: World Development, 35(8), 1329-40.

David, A.C. (2008): Controls on capital inflows and the transmission of external shocks, in: Cambridge Journal of Economics, 32, 887-906.

Dyer, G. (20II): China plays down levels of 'hot money`, in: Financial Times, is February.

Edison, H. (1987): Purchasing power parity in the long run: A test of the dollar/pound exchange rate (1890-1978), in: Journal of Money, Credit and Banking, I9(3), 376-87.

Edison, H., Reinhart, C.M. (200I): Stopping hot money, in: Journal of Development Economics, $66,533-53$.

Epstein, G., Grabel, I., Jomo, K.S. (2004): Capital management techniques in developing countries: An assessment of experiences from the r990s and lessons for the future, G-24 Discussion Paper Series, Geneva: UNCTAD.

Flassbeck, H. (2005): China's spectacular growth since the mid-I990s - macroeconomic conditions and economic policy challenges, in: China in a Globalizing World, Geneva: UNCTAD.

Friedman, M. (1953): The Case for Flexible Exchange Rates, Essays in Positive Economics, Chicago: Chicago University Press.

Garcia, M., Valpassos, M. (1998): Capital flows, capital controls and currency crisis: The case of Brazil in the nineties, Discussion Paper no 389, PUC-Rio. 
Goodhart, C.A.E., Delargy, P.J.R. (1998): Financial crises: Plus ça change, plus c'est la même chose, in: International Finance, I(2), 26I-87.

Gopinath, S. (2OII): Approach to capital account management - shifting contours, Thimpu, I8 February, BIS central bankers' speeches.

IMF (2007): Reaping the benefits of financial globalization, Discussion Paper, June.

IMF (2007a): Reaping the benefits of financial globalization, Discussion Paper, June, http:// www.imf.org/external/np/pp/2007/eng/062907.pdf

IMF (20I0): The Funds role regarding cross-border capital flows, November 15.

Johnson, H.G. (1969): The case for flexible exchange rates, Federal Reserve Bank of St. Louis, June.

Keynes, J.M. (1973/1939): The Process of Capital Formation, in: Economic Journal, repr. in: Moggridge, D. (ed.), The collected writings of John Maynard Keynes. London: Macmillan, vol. I4, 278-85.

Krugman, P. (2010): Chinese New Year, in: New York Times, January I.

Lane, P., Milessi-Ferreti, G.-M. (2007): The external wealth of nations mark II: Revised and extended estimates of foreign assets and liabilities: 1970-2004, in: Journal of International Economics, 73(2), 223-50.

Leahy, J. (20II): Brazil's real eases after shortselling curbs, in: Financial Times, 6 January.

Leahy, J., Pearson, S. (20II): Brazil to curb spending on housing, in: Financial Times, 28 February.

Loungani, P., Mauro, P. (2000): Capital flight from Russia, IMF Policy Discussion Papers oo/6, International Monetary Fund.

Ma, G., McCauley, R.N. (2007): Do China’s capital controls still bind? Implications for monetary policy autonomy and capital liberalization, BIS Working Paper no. 233, August.

Ma, G., Haiwen, Z. (2009): China's evolving external wealth and rising creditor position, BIS Working Paper no. 286, July.

Mackenzie, M. (20II): China holds \$I,I6obn of US debt, in: Financial Times, I March.

Magut, E.N., Reinhart, C.M., Rogoff, K.S. (20II): Capital controls: Myth and reality - A portfolio balance approach, NBER Working Paper no. I6805.

McMahon, D. (20I0): In China, foreign banks lag behind, in: Wall Street Journal, is September.

Mohan, R. (2008): Capital flows to India, BIS Papers no. 44, $235-63$.

Ocampo, J.A., Stiglitz, J.E. (eds.) (2008): Capital Market Liberalization and Development, New York: Oxford University Press.

Oster, S., McMahon, D., Lauricella, T. (20I0): Offshore trading in yuan takes off, in: Wall Street Journal, I4 December.

Ostry, J.D., Ghosh, A.R., Habermeier, K., Chamon, M., Qureshi, M.S., Reinhardt, D.B.S. (2010): Capital inflows: The role of controls, IMF Staff Position Notes, No. Io/o4, I9 February.

Ostry, J.D., Ghosh, A.R., Habermeier, K., Laeven, L., Chamon, M., Qureshi, M.S., Kokenyne, A. (20II): Managing capital inflows: What tools to use?, IMF Staff Discussion Note, II/06, 5 April.

People's Bank of China (2008): China: the evolution of foreign exchange controls and the consequences of capital flows, BIS Papers no. 44, I43-5I. 
Pérez Caldentey, E. (20II): The financial system before and after the global crisis, Paper presented at the Eastern Economic Association meeting, New York, February.

Prasad, E.S., Rajan, R.G. (2008): A pragmatic approach to capital account liberalization, in: Journal of Economics Perspectives, 22(3), I49-72.

Prasad, E.S., Rajan, R.G., Subramanian, A. (2007): The paradox of capital, in: Finance and Development, 44(I).

Rogoff, K. (1996): The purchasing power parity puzzle, in: Journal of Economic Literature, 34, $647-68$.

Sen Gupta, A. (2010): Management of international capital flows: The Indian experience, MPRA Paper no. 23747, July.

Shah, A., Patnaik, I. (2008): Managing capital flows: The case of India, Working Paper 200852, National Institute of Public Finance and Policy, May.

Shah, A., Patnaik, I. (20II): India's financial globalization, National Institute of Public Finance and Policy, Working Paper 20II-79, January.

Summers, L.H. (2006): Reflections on global current account imbalances and emerging markets reserve accumulation, L.K. Jha Memorial Lecture, Reserve Bank of India, March.

Taylor, L. (2004): Exchange rate indeterminacy in portfolio balance, Mundell-Fleming and uncovered interest parity models, in: Cambridge Journal of Economics, 28, 205-227.

Tobin, J. (1974): The New Economics. One Decade Older, New Jersey: Princeton University Press.

United Nations (2010): The Stiglitz Report: Reforming the International Monetary and Financial Systems in the Wake of the Global Crisis, New York: The New Press.

United Nations (201I): World Economic Situation and Prospects 20II, New York.

UNCTAD (2006): World Investment Report, Geneva.

UNCTAD (2010): Trade and Development Report, 2010, Geneva.

Wei, L. (20II): New move to make Yuan a global currency, in: The Wall Street Journal, I2 January. Yongding Yu (2008): Managing capital flows: The case of the People's Republic of China, ADB Institute Discussion Paper no. 96, March.

Yue, E. (2OII): Hong Kong as an international financial center - the China factor, New York, I March, BIS Central Bankers' speeches.

Zhang, K.H. (2009): Rise of Chinese multinational firms, in: The Chinese Economy, 42(6), 8I-96. 